\title{
A CIDAdE DE SÃO PAULO NO SÉCULO XX.
}

\section{SÃO PAULO TRANSFORMA-SE EM METRGPOLE INDUSTRIAL.}

Os cinqüenta anos já decorridos, no século atual, foram assinalados por um fato novo, cujas origens remontam à última década do oitocentismo: o surto industrial, que veio transformar a "metrópole do café" ou "a capital dos fazendeiros" na dinâmica e movimentada metrópole industrial de nossos dias.

De acôrdo com os dados de Bandeira Júnior (1), foi o seguinte o crescimento das indústrias paulistanas; no decorrer do século XIX:

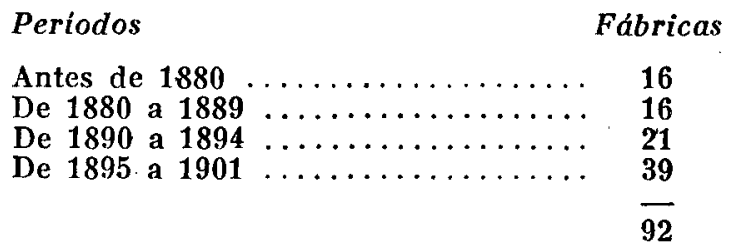

$\mathrm{Na}$ verdade, nos últimos 50 anos, importantes acontecimentos mundiais vieram repercutir extraordinàriamente sôbre a capital paulista, fazendo com que nela surgisse seu grande parque industrial: a primeira Grande-Guerra (1914-18), a crise econômica decorrente do "crack" de 1929 e a última conflagração mundial (1939-45).

Os que escreveram sôbre a cidade na primeira década do século XX sentiram, já, a importância dessa nova função urbana. Manuel Bernárdes considerou São Paulo "una verdadera metrópole industrial y económica del Estado, y quizás de la Unión" (2). Pierre Denis classificou a cidade como "un gros centre industriel" (3) e Paul Walle, confessando sua surpreza ante o inacreditável desenvolvimento da indústria no Estado, afirma que "la capitale est devenue un important centre manufaturier, le second du Brésil après Rio de Janeiro" (4).

\footnotetext{
(1). - BANDEIRA JÚNIOR (Antonio Francisco), A Indústria no Estado de São Paulo em 1901, Tip. do "Diário Oficial""; São Paulo, 1901

(2). - BERNARDES (Manue1), El Brasil — su vida, su trabajo, su futuro, pág. 193 Buenos-Aires, 1908.

(3). - DENIS (Pierre), Le Brésil au XXXe. siècle, pág. 112, 4a, edição, Liv. Armand Còlin,. Paris, 1911.

(4). - WALle. (PAUL), Au Brésil - De l'Utuguay au Rio São Francisco, pág. 160, Lib. Orientale Américaine, E. Guilmoto, Paris 1910.
} 
Uma série de fatôres, além dos citados, se conjugaram para ocasionar o desenvolvimento e o fortalecimento do parque industrial paulistano: 1. a facilidade de obtenção da energia elétrica, que sòmente nos últimos anos veio a tornar-se escassa, criando um problema angustiante; 2 . a existência de um mercado consumidor interno, que se tornou cada veź maior em virtude do crescimento da população da cidade e do Estado; 3. o afluxo de capitais, tanto estrangeiros como nacionais, "póssibilitando o aparecimento de grandes indústrias; 4 . a facilidade de mão de obra operária, a princípio oriunda da massa imigrada, mais tarde resultante da crise cafeeira de 1929-30 e do incessante êxodo dlas áreas rurais; 5 . a existệncia de um mercado fornecedor de matérias primas, dentro do próprió Estado (no que se refere ao algodão, notadamente) ou fora dêle; 6. a importante rêde de transportes, que tem na cịade de São Paulo o seu fulcro (5):

Ao findar a terceira década do presente século, São Paulo aparecia como o maior centro industrial da América do Sul. Possuindo pouco menos de 2.000 estabelecimentos fabrís em 1918 (6), tinha em 1932 cêrca de 2.100 (7); mas, em 1947, êste número elevava-se a 12.000 (8) e, hoje pode ser calculado em 20.000, onde exercem sua atividade nada menós de 440.000 .operários e de onde sai mais da metade da produção industrial de todo o país.

A "metrópole industrial", assim surgida, ainda não repousa em bases muito sólidas: foi incrementada por acontecimentos anormais (como as duas Grandes-Guerras) e por situações artificiais, decorrentes da política protecionista; não conta com o necessário potencial de energia, capaz de atender às suas exigências sempre crescentes; precisa preocupar-se sempre com o problema de maquinários e com o fornecimento de certas matérias primas e outras fontes de energia; embora tenha diante de si amplas perspectivas no que se refere aos mercados consumidores, sofre a çoncorrência de outros centros industriais de destaque, desenvol vidos no interior do próprio Estado de São Paulo (9).

\footnotetext{
(5). - Consulte-se, sôbre ○ assunto: PETRONE (Pasquale). As Indústrias paulis= listanas e os fatôres de sua expansão," em "Böletim Paulista de Geografia", n." 14, Sāo Paulo, julho de 1953; e MONBEIG (Pierre), La croissance de la ville de São Paulo, págs. 50-57, ed. do Iristitut et Revue de Geographie Alpine, Grenoble. 1953.

(6). - Cf. PESTANA (Paulo Rangel) em A. Capital Paulista comemorando o Centenário da Independência, ed. Sociedáde Editôra Independência, Sāò Paulo,1920.

(7). - Cf. QUEIROZ (Vitorino Seixas) e ARANTES JUNIOR (Lourenço), Os Municípios do Estado de São Paulo - Informaçōes interessantes; págs. 107-108, Diretoria de Publicidade Agricola da Secretaria da Agricultura do Estado, São Paulo, 1933 .

(8). - Cf. BRazII (Raimundo Pereira). São Pauto, fôrça económica, pág: 204, Emp. Gráfica Revista'dos Tribunais", São Paulo, 1949

(9). - Sóbre o assunto, veja-se: JAMEs (Preston), Brasi7, págs. 150-151, The Odyssey Press, New-York, 1946; MONBEIG . (Pierre), obra cit ., págs. 52-57; $\theta$ PETRONE. (Pasquale), 'obra cit., pag. 37.:
} 
Todavia, coube à indústria paulistana o importante papel de haver valorizado o produto nacional, outrora sempre despreza'do e preterido pelo produto estrangeiro, muitas vêzes de qualidade inferior. Coube-the, outrossim, aumentar o poderio econômico da cidade, fazer surgir "millionaires" mansions such as the U.S. has not seen since the days of Carnegie and Frick" (10) e, principalmente, influir poderosamente sôbre a área da cidade, sua população e a própria paisagem urbana.

\section{A EXPANSÃO INDUSTRIAL E SEUS REFLEXOS SôBRE A CIDADE.}

Quando se comparam as plantas da cidade de São Paulo referentes à última década do século XIX com as que correspondem às diversas etapas de sua vida no século atual (11), nota-se que São Paulo expandiu-se em tôdas as direções, mas que foi para Oeste, para Leste e para o Sul que tal expansão verificou-se com maior intensidade. Ora, exatamente em tais direçóes localizam-se as mais importantes e características áreas industriais da capital paulista.

Não resta dúvida que as principais áreas industriais acompanham as vias-férreas: Brás, Belenzinho, Tatuapé, Comendador Ermelindo e São Miguel Paulista, ao longo dos trilhos da "Central do Brasil"; ainda o Brás, Parí, Mooca, Ipiranga, São Caetano do Sul e Santo André, acompanhando a Santos-Jundiấ"; Barra Funda, Água Branca, Lapa e Osasco, servidas tanto por esta via-férrea, como pela "Sorocabana". Mas, inegàvelmente, foi a função industrial, mais do que outro qualquer fatôr, que ocasionou seu crescimento e sua expansão em área. $O$ fato de terem as estradas de ferro aproveitado cs vales, onde os terrenos podilam ser obtidos a baixos preços por não serem apreciados como locais de residência, atraiu a instalação de estabelecimentos fabrís. Cresceu, dêste modo, a área ur-

(10). - City of Enterprise em "Time" (Edição latino-americana), pág. 20, New-York, 21 de ajeniro de 1952 .

(11) - Consulte-se, principalmente: Planta da Cidade de São Paulo, levantada e organizada pelo eng..$^{\circ}$ civil ALEXANDRE MARIANO COCOCI e LIJIS FRUTUOSO DA COSTA, na escala de 1:20.000. edições de 1905 e 1913; Planta Geral da Cidade de São Paulo. organizada pela Comissão Geográfica e Geologica do Estado, sezdo chefe o eng. Joäo Pedro Cardoso, na escala de 1:20.000, 1914: Planta da Cidade de São Pauio, com todos os arrabaldes e terrenos arruacios. executada por VALDOMIRO GONÇALVES. na escala de 1:26.000, 1924; Carta dos Excerrsionistas (1.a seç̧ăo), organizada pelo INSTITUTO ASTRONÓMICO E GEOGRÁFICO do Estadó, na escala de 1:200.000, 1924, reeditada em 1935; Planta da Cidade de São Paula e municípios circunvizinhos, organizada pela Repartiç̃̃o če Eletricidade da LIGTH AND.POW/ER, na escaía de 1:40.000. 1926-27; Mapa Topógráfico do Município de São Paulo, executado pela empresa SARA DO BRASIL, S.A., pelo método Nistri de aerofotogrametria. nas escalas de 1:20.000 e 1:5.000, 1939; Planta de Säo Paulo, por JOSE CASTIGLIONE, na escala de 1:20.000, 1941; e. Mapa do Municipio e da Cidade de São Pauto, organizado por L. STRINA \& CIA., na escala de $1: 20.000,1944$ 
banizada e as várzeas do Tamanduateí e do Tietê, naqueles trechos, deixaram de ficar ao abandono.

Não é só. O surto industrial ainda influiu sôbre a cidade, concorrendo para o aumento da população (em virtude da crescente necessidade de mão de obra e impulsionado pela "miragem" que vive a atrair, para a metrópole, a população da zona rural e do interior, em geral) e, sobretudo, modificando a paisagem urbana e acabando por concretizar a existência do "Grande São Paulo".

No que se refere à paisagem urbana, cumpre observar que, em São Paulo, não se formaram áreas tipicamente industriais, exclusivamente ocupadas por fábricas. Sendo o parque industrial paulistano caracterizado pelo predomínio de fábricas de tamanho médio e pequeno, testinadas principalmente à transformação, o que se presencia é a intercalação de estabelecimentos fabrís no meio de residências proletárias e, conseqüentemente, o aparecimento de verdadeiros bairros mixtos, industriais e residenciais a um só tempo.

Dentro do perímetro urbano em zonas como o: Brás a Miooca e o Belenzinho quase sempre térreas e sem nenhum jardim à frente, geralmente geminadas (duas a duas quatro a quatro), tôdas mais ou menos iguais, tie estilo pobre ou indefinivel. Extendem-se assim, em sua monotonia e em sua humildade, em filas intermináveis, que. chegam a ocupar quarteirões inteiros. No meio delas, porém, surgem de quando em vez a pesada e característica fachada de uma. fábrica ou, então, pequenas oficinas ou fabriquetas. Estas são mui-. to numerosas. aparecendo instaladas numa casa igual às demais. em antigas garagens, em barracões ou simples telheiros, no fundo de quiritais. Já as fábricas maiores se d'estacam, quando não por suas chaminés, pelo menos pela grande extensão de suas fachadas e seu amplo portão de entrada.

A presença da ferrovia acrescenta novos elementos a essa. paisagem: são as passagens de nível, com suas porteiras e periódicos estrangulamentos do tráfego; são as estações e os respectivos. páteos de mancbras, sempre movimentados e barulhentos; são cs grandes armazens de mercadorias, alinhados ao longo das vias-férreas; são as ruas de traçado irregular, que muitas vêzes não tem. saida.

Nas áreas suburbanas, a paisagem é bastante diferente. Nota-se uma diferenciação mais nítida entre a zona fabril e a zona residencial não se registra a mesma concentração do "habitat", aparecendo as fábricas de maneira esparsa e ocupan'do áreas muito maiores, sem falar nos terrenos reservados para futuras ampliaçóes. Surgem "vilas" operárias, que se instalam na própria área. urbanizada oư até mesmo na zona rural. 
Estará completo êsse quadro correspondente à paisagem criada pela indústria na capital paulista? $\mathrm{E}$ evidente que não, pois é preciso fazer uma referência, pelo menos: ao borborinho das ruas, que se intensifica nas horas de entrada e de saída nas fábricas, quando, ao soar das sereias, um enxame de homens, mulheres e menores enche as calçadas, dando vida e movimento às ruas; aos variados meios de transporte de que se utilizam os operários - bicicletas, ônibus, bondes, caminhões arvorados em veículos para passageiros, trens suburbanos, tomados de assalto por essa pequena multidão que anseia voltar para suas casas; aos bares ou simples botequins, que se instalam nesses bairro industriais, porque a freguesia é certa e numerosa; aos vendedores ambulantes, sobretudo de comestíveis, sempre apreciados, embora nem sempre limpos; e, finalmerite, ao padrão de vida geralmente baixo da população que ali vive, que bem pode ser simbolizado pela imundície das calçadas, pelo aspecto desleixado das crianças e pela sordidez das habitações, muitas delas de caráter coletivo, miseráveis "cortiços" da grande metrópole.

Abrindo novas áreas industriais na periferia da cidade, em busca de terrenos de menor preço e de maiores espaços, condicionada quase sempre pela proximidade das vias-férreas, a expansão industrial vem concorrendo para a formação e o fortalecimento do que poderemos chamar o Grande São Paulo, a exemplo do que se verifica com as maiores aglomerações urbanas do planeta Nova York, Londres, Paris, Berlim, Moscou ou Tóquio. No caso paulista, o fenômeno é tão palpável e evidente que a própria administração pública terá de lhe dar uma solução adeqüada, dentro de breve tempo.

O desmesurado crescimento da cidade, com efeito, já não mais comporta um sistema administrativo, como o atualmente existente. Tudo parece indicar a necessidade de descentralizar a administração municipal; e a criação de sub-prefeituras ou, mesmo, de prefeituras subordinadas a um órgão administrativo superior, parece ser a solução mais adequiada à importância do problema.

O fenômeno, ainda em pleno processo, mas impulsionado por fôrças irresistiveis, consiste na aglutinação de núcleos próximos pela metrópole paulista. Não se trata de um fato novo na evolução da cidade de São Paulo: no passado, a Penha, a Freguezia do ó, a Lapa, Pinheiros viveram, por muito tempo isolados da cidade mas acabaram sendo alcançados pelos seus tentáculos e confundiram-se na massa de seus bairros periféricos. Nos casos citados foi a cidade que chegou até êles, envolvendo-os em sua trama. No momento atual, porém, o que se presencia, é algo de diferente e de proporções muito maiores: trata-se de verdadeiros exemplos daquilo que os 
geógrafos franceses vêm designando pelo nome de conurbação ou, talvez melhor, conurbanização (12).

Na verdade, em tôrno da cidade de São Paulo e no presente século, desenvolveram-se extraordinàriamente alguns aglomerados urbanos, como Santo André, São Caetano do Sul, Santo Amaro e Osasco. Salvo Santo Amaro, cuja fundação remonta aos tempos coloniais, todos êles se formaram nos últimos 60 anos; mas até recentemente, permaneceram mais ou menos estagnados. Graças notadamente ao desenvolvimento industrial, tais núcleos puzeram-se a crescer nos últimos anos, em ritmo comparável ao da metrópole se bem que em menores proporçc̃es; suas áreas urbanizadas passaram a expandir-se em direção à cidade de São Paulo, ao mesmo tempo que esta avançava também na direção daquelas. Hoje, pràticamente já se encontraram essas "frentes" expansionistas; e tudo isso se deve notadamente às indústrias, instaladas simultâneamente tanto num como noutros.

Na direção a São Caetano do Sul e Santo André, a expansão de São Paulo fêz-se atravéz dos bairros localizados à margem direita đo Tamanduateí (Vila Prudente, Vila Isolina, Vila Califórnia, etc.) e por intermédio da Estrada de São Caetano, que sai do Sacomã. Cumpre assinalar que o crescimento não se fêz ao longo da via-férrea, mas paralelamente, em terrenos mais elevados; é que, junto dela na várzea, acham-se instalados muitos estabelecimentos fabrís.

No rumo de Osasco, a expansão seguiu três direções: da Lapa, acompanhando a via-férrea, através de Domingos de Morais e Presidente Altino; do Alto da Lapa, seguindo pela margem do Pinheiros, através da Vila Jaguaré; e de Pinheiros, através do Butantã, acompanhando a Estrada de Itú.

Para Santo Amaro, o crescimento foi maciço ,embora por meio de caminhos diversos: seguindo a linha de bondes, através do Brooklyn Paulista; em continuação à Vila Mariana, por intermédio do Ja. baquara; através da região de Congonhas, por meio da Auto-Estrada; e pela atual avenida antiga Estrada de Santo Amaro.

Em conseqüência dessa insopitável expansão (que se viu acompanhada por outra, em menor ritmo, partida dos pontos visados), extensas áreas rurais ou semi-rurais muitas vêzes desocupadas, existentes de permeio, foram sendo pouco a pouco urbanizadas e os "vazios" de outrora deixaram de existir, em muitos casos. Por essa forma, trechos já pertencentes ao municıpio de São Paulo e outros integrantes de municípios vizinhos de São Paulo e outros integrantes de municípios vizinhos (como é o caso de São Caetano do

(12). - Consulte-se entre outros: SORRE (Max.). Les Fondements de la Céographie Humaine, tômo III (L'habitat), Liv. Armand Colin. Paris. 1952; E. GEORGE (Pierre), La Ville - Le fait urbain à travers le Monde, ed. Presses Universitaires de France, Paris. 1952 . 
Sul e Santo André) passaram a integrar o enorme aglomerado paulistano, que prevaleceu por ser maior e por dispor de uma pluralidade funcional não conhecida em seus vizinhos. E o "Grande São Paulo", mais do que antes, concretizou-se.

Torna-se interessante regîtrar g̨ue idêntion processo de "conurbanização" já se tinha verificado em relação a Santo André e São Caetano do Sul; e o mesmo está em vias de se realizar entre Santo André e São Bernardo do Campo. Aliás, compreenden'do perfeitamente as identidades que os aproximam e no desejo de resolver. em comum determinados problemas, as autoridades municipais dêsses três municípios constituiram uma espécie die "entente" - o chamado A.B.C., que sintetiza os nomes dos três santos patronímicos daquelas cidades.

FISIONOMIA DA CIDADE NO PRIMEIRO QUARTEL DO SECULO XX.

De tudo quanto deixamos escrito, não se conclua, porém, que haja sido o desenvolvimento industrial o único fator do crescimento da cidade de São Paulo nos 50 anos decorridos do presente século. Outros muitos fatôres também concorreram com sua parcela, particularmente: o ininterrupto desenvolvimento econômico do Estado, que the assegurou a liderança dentro do país, neste particular; o conseqüente e paralelo desenvolvimento da função comercial; $\mathbf{e}$; naturalmente, a preeminência político-administrativa que a cidade, por ser a capital, continuou a usufruir dentro das terras paulistas e, mesmo, fora delas, num âmbito cada vez mais vasto, que Preston James soube fixar com muita fidelidade (13). Tudo isso ressaltará do exame, que faremos a seguir, das grandes etapas dêsse crescimento e das respectivas características, marcadas de maneira inegável na fisioniomia da cidade.

Para Afonso A. de Freitas, que escreveu nos primeiros anos do século atual, São Paulo era "uma bela cidade", "muito comerciante e industriosa" (14). Seria certamente bonita, pois outra: fonte, menos suspeita, considerava-a "uma das mais belas da União, reconstruida e aumentada com apuro artístico" a partir de 1890 (16). Embora acentuando que nada tinha 'de pitoresco, como situação e como aspecto, Paul Walle viu nela "une belle ville active et vivante" (16). Já era, nessa primeira década do novecentismo, "a capital económica do Brasil", no dizer de Manuel Bernárdes (1\%). Além de considerá-la um grande centro industrial, Pierre Denis sentiu perfei-

\footnotetext{
(13). - JAMES (Preston, obra cit., cap. V

(14) - FREITAS (Afonso A. de), Geografia do Estado de São Paulo, pág. 50, Escolas Profissionais Salesianas, São Paulo, 1906.

(15) . - Cf. Almanaque Brasileiro para o amo de 1907, ano V, pág. 181. ed, Guarnier, Rio.

(16) - WALLE (Paul), obra cit., pág., 151.

(17). - BERNARDES (MANUEL); obra cit.. pág. 202
} 
tamente sua função comercial, pois era "avant tout une grande ville d'affaires", o "mercado central de um território ativo, onde a circulação do dinheiro se faz rápida"; mas, percebeu nela a existência de um "mercado de homens", porque era o centro distribuidor de imigrantes para as regiões cafeeiras, como também constituia um foco de atração da mão de obra precedente das zonas rurais; e deu o merecido valor à sua função cultural (19). Finalmente, Marie R. Wright definiu-a bem, quando escreveu: "Como capital do Estado, São Paulo é o lugar de residência de muitos homens públicos e políticos de 'destaque; como grande centro educacional, atrai um grande número de estudantes; e como centro distribuidor das indústrias do interior, é a residência de ricos e numerosos capitães da indústria, de São Paulo" (19), ao mesmo tempo que a classificou como "moderna metrópole" (20).

"Extendendo-se desmesuradamente sôbre o planalto, São Paulo traz, na desordem de sua estrutura, o traço de seu precoce crescimento, embora ali reinem a animação e o movimento de uma grande cidade. Os bairros comerciais são ruidosos; o fechamento das fábricas e dos escritórios enche as ruas de transeuntes" escreveu Pierre Denis (21). Segundo êle, no Brasil daquele tempo, São Paulo e Rio de Janeiro eram as únicas cidades onde se podia encontrar uma multidão. Por outro lado, impressionou-o a perfeita coesão existente entre a cidade e o campo, que se achavam estreitamente ligados por comuns interêsses (22), observação de alto valor, pois parece indicar que, sob certo aspecto, São Paulo continuava sendo "a capital dos fazendeiros".

Embora ficasse admirado com "o prodigioso aumento de sua prosperidade e de sua população" e prognosticasse uma marcha sempre ascendente, Paul Walle achou São Paulo uma cidade triste e sem distrações: quando soavam 6 horas da tarde e o comércio se fechava, uma pesada solidão descia sôbre as ruas comerciais e o silêncio tornava-se tão profundo, como se a cidade tivesse sido abandonada (23).

L. A. Gaffre anotou a existência de bonitos bairros novos, com ruas largas e opulentamente arborisadas, "onde se sucediam indefinidamente pequenas casas de estilo italiano, com balaustres, cornijas, decorações de estuque e estatuetas simbólicas coloridas", em que leões montavam guarda nas extremidades dos muros e as ja-

(18). - DENIS (Pierre), obra cit., pág. 111 e 112-113.

(19): - WRIGHT (Marie Robinson), The New Bhazil - Its resources and attractions - Historical, descriptive and industrial, pág. 207, 2.a edição, ed. George Barrie \&o Sons, Filadélfia, 1907.

(20). - WRIGHT (Marie Robinson), obra cit., pág. 213

(21). - DENIS (Pierre), obra cit., pág. 112.

(22). - DENIS (Pierre), obra cit., pág. 112.

(23). - WALLE (Paul), obra cit., págs. 151 e 155. 
nelas, largamente abertas, permitiam que os olhares indiscretos devassasem seu interior. Extranhou a inexistência de flôres às janelas, mas verificou que outras, mais belas e mais vivas, ali ficavam horas a fio: as mulheres paulistanas (24) ... Encantou-se ao penetrar na intimidade do lar de uma das importantes famílias da época e testemunhou que a influência da cultura francesa continuava a ser total (25). Neste particular, George Clemenceau chegou a afirmar que a cidade de São Paulo era tão curiosamente francesa em alguns de seus aspectos que, no decorrer de tôda uma semana, esqueceu-se êle de que se achava no estrangeiro (26).

Sob a influência de um entusiasmo certamente exagerado e abusando dos adjetivos, Roberto Capri deixou-nos um retrato da cidade, por volta de 1812: “A Capital é essa cidade quase europeia, tôda coalhada de construções magníficas no belo estilo italiano, tôda cortada de ruas e avenidas, com fábricas por tôda parte, edifícios públicos suntuosos, uma vida larga e intensa, uma população já quase de meio milhão de habitantes"; tudo ali crescia vertiginosamente e, "a par de tơdo êsse avanço material, a instrução pública, esmeradamente zelada e as artes e ciências florescem" (27). - Oito anos mais tarde, cada vez mais entusiamado, considerou São Paulo a "capital artística" do Brasil (28). Entretanto, nem tôdas as impressões de viajantes estrangeiros que aqui estiveram foram totalmente favoráveis; Ernst von Hesse-Wartegg, no primeiro decênio deixou-nos as séguintes linhas sôbre a cidade: "A primeira impressão que obtive de São Paulo no longo trajeto da estação atravéz de suas ruas que scbem e descem me decepcionou bastante e eu tive a sensação de que estava caminhando atravéz de qualquer das grandes cidades 'do sul da América do Norte, talvez Wilmington ou Atlanta ou Lcuisville, mas não atravéz do maravilhoso país tropical que é o Brasil. E quando nas duas semanas seguintes fiquei conhecendo mais de perto a cidade, e suas instituições, não consegui mudar de opinião. São Paulo não é uma cidalde brasileira de 450.000 habitantes, mas uma cidade italiana de aproximadamente 100.000, uma portuguêsa de talvez 40.000, uma espanhola de igual tamanho e uma pequena cidade (Kleinstadt) alemã de mais ou menos 10.000 habitantes, com poucas de suas vantagens, mas muitas d'e suas desvantagens. Ainda há uns 5.000 sírios, que sòzinhos possuem três jornais impressos em caracteres arábicos, alguns mil fran-

\footnotetext{
(24). - GAFFRE (L.A.), Vision du Brésil, págs. 151-153, ed. Aillaud, Alves \& Cia., Paris, 1912 .

(26). - GAFFrE (L.A.), obra cit., págs. 198-200.

(26). - Cf. São Paulo e seus homens no Centenário, vol. I, pág. 67, Emp. Publiblicidade Independência Editôra, São Paulo, 1922.

(27). - CAPRI (ROBERTO), O Estado de São Paulo e seus Municipios. págs. 12-13, Tip. Pocai \& Weiss, São Paulo, 1913.

(28). - CAPRI (ROBERTO). São Paulo, a Capital Artística, na comemoração do Centenário," São Paulo. 1922.
} 
ceses, russos, japoneses, poloneses turcos ainda inglêses escandinavos, americanos em número desconhecido por falta de uma estatística fidedigna. O resto, provàvelmente um terço do total, dévia ser de. brasileiros" (29).

A documentação cartográfica da época $e$ as obras que pudemos consultar fornecem-nos elementos suficientes para que possamos fixar a área urbana, na primeira déca'da do século atual. Dois importantes blocos constituiam a cidade e o divisor entre ambas era representado pela várzea do Tamanduateí. Tal separação apresentava-se, com maior nitidez, entre o Cambuci e a Mooca e na chamada Várzea do Carmo (atual Parque Dom Pedro II). As duas áreas interpenetravam-se, porém, no Parí e na Luz, embora através de número reduzido de ruas.

Esses dois blocos formavam, então, duas cidades distintas, como se fôssem duas cidades gêmeas; e só recentemente, na verdade, vieram a unir-se. De um lado, apareciam o velho centro e os bairros das zonas Oest., Sudoeste e Sul; de outro lado, o Brás e seus prolongamentos no rumo de Leste (30).

O centro da cidade continuava a ser presidido pelo tradicional "Triângulo" (ruas de São Bento, Direita e Quinze de Novembro), com suas ruas tortuosas e estreitas, "bordejadas por belas lojas e casas vastas e sólidas, de bonita arquitetura" (31). O Largo do Rosário era o mais movimentado, embora o coração da cidade estivesse. na rua Quinze de Novembro, "a rua do Ouvidor de São Paulo" (32). Em suas "ruas agitadas se processavam os negócios políticos e comerciais, trabalhava o cérebro e batia o coração de São Paulo" (33).

Em direção ao Sul, apareciam os bairros da Liberd'ade, Bela-Vista e Consolação. Para Oeste, Santa Ifigênia, Campos Elíseos, Bom Retiro e Barra Funda. Vila Buarque já se achava totalmente. formada, mas Santa Cecília apenas se esboçava como bairro. Higienópolis era, na época, o bairro aristocrático da cidade, após haver destronado o dos Campos Elíseos. A Avenida Angélica ainda não. se povoara e a Avenida Paulista, embora ainda com vazios, já era. o orgulho dos paulistanos. Assistia-se a uma alta constante no valor dos terrenos nesses novos bairros, onde "os negociantes, os altos funcionários e os ricos fazendeiros do interior" tinham feito

\footnotetext{
(29). - HESSE - WARTEGG (Ernst von), Zwischen Anden und Amazonis, 2.a edi-

(30). - Aläo. Union das plantas da vedlogsgesellschaft. Stuttgart, 1915, pág. 149. de Marie Róbinson WRIGHT, Manuel BERNARDES. Paul WaJLE a L. A. GAFFRE, também já citaćas, e mais: MARQUES (Cícero), Do Pastora a Rainha. São Paulo, 1944; MOURA (Paulo Cursino de), São Pavto de Outrora, edL Melhoramentos, São Paulo. 1932; BRUNO (Emani Silva), História e Tradições da Cidadé de São Paúlo, vol. III, ed. José Olímpio, Rio,. 1954 .

(31). - WALlE (Paul), obra cit.. pág. 151

(32). - WALLE ! ( Paul), obra cit.. pág. 152.

(33). - GAFFRE (L.A.), obra cit., pág. 158.
} 
construir "casas mais ou menos bonitas, mas sempre vastas e cômodas" (34). A Vila Cerqueira César estava apenas arruada. O conjunto com a av. São João e rua Vergueiro, passou a formar a primeira "circular" de São Paulo (radial concêntrica), que influiu poderosamente na expansão da cidlade pare o sul.

O bairro de Higienópolis era, sem nenhuma dúvida, nessa época, o mais elegante da cidade. Marie Wright, informa que ali muitos dos milionários paulistas tinham "palatial homes, unsurpassed in splendor and luxury by the great mansions of Europe" (35). Ponto de reunião do que a cidade e o Estado possuiam de mais rico e de mais distinto, diz Paul Walle, notabilizava-se pelo elevado número de casas suntuosas, palacetes luxuosos e confortáveis, embora alguns deles fôssem "d'un gout douteux, tout au moins bizatre" ... (36).

A Avenida Paulista, por sua vez, constituia algo de representativo daquela cidlade que se tornava cada vez mais rica e mais próspera. E os estrangeiros também se embasbacavam diante dela Marie Wright chama-a de "magnificent" e considera "the most beautiful boulevard of the capital" (37). Manuel Bernárdes, classificando-a de "dilatada y vistosa", encantou-se com "el frescor umbrio de sus alamedas" e, principalmente, do belíssimo panorama que dela se descortinava, podendo ver a cidade "con sus treinta alamedas, sus veinte plazas, sus cuarenta y una avenidas, sus novecientas calles" (38). E L. A. Gaffre, chamando-a de esplêndida, diz que só poderia compará-1a a "certaines avenues de New York. où la fantaisie des millionnaires américains encercle dans la verdure des grandes arbres et la polychromie des parterres, leur palais aux élégantes sculptures"; e fica assombrado quando the vão indicando os principais proprietários daquelas residências luxuosas: aqui, um grande nome de velha estirpe lusitana; ali, um entigo vendedor ambulante, um "mascate" há 25 anos atrás, transformado em grande senhor, des. cendente talvez de velhos mercadores de Veneza ou de Gênova ... (39). Assim era São Paulo nesse comêço de século.

$\mathrm{Na}$ direção de leste, separado pela várzea do Tamanduateí, aparecia o bloco compacto do Brás, que se prolongava até às proximidades da estação da Mooca (na então "São Paulo Railway") e alcançava o Belenzinho. O Parí já estava, pràticamente, unido ao Brás. A Avenida Rangel Pestana, uninddo o centro da cidade e êste populosło bairro, terminava no Largo da Concórdia, onde existia um mercado (40), e via-se prolongada pela Avenida da Inten-

\footnotetext{
(34). WALLE (Paul), obra cit., pág. 152.

(35). - WRIGHT (Marie Robinson), obre cit., pág. 212.

(36). - WALLE (Paul). obra pit., pág. 152.

(37). - WRIGHT (Marie Robinson), obra cit., pág. 212

(38). - BERNARDEZ (Manuel) obra cit., pág. 189.

(39). - GAFFRE (L.A.), obra cit., pág. 159.

(40). - WRIGHT (Marie Robinson), obra cit., pág. 212
} 
dência, no rumo da Penha. Em direção ao norte, para além do bairro 'da Luz, a Avenida Tiradentes, "bordejada em tôda sua e tensão por habitações elegantes e por jardins" (41), alcançava os margens do Tietê e punha a cidade em contacto com a região da Cantareira, através de Sant'Ana.

O Brás, "immense quartier populaire et laborieux" passava, então, por importantes melhoramentos e preparava-se para receber os benefícios da iluminação elétrica e da pavimentação (42).

Pode-se perceber, com relativa facilidade, quais eram, por essa época, os rumos prováveis da expansão da cidade: na direção de Oeste e de Noroeste, através da Avenida Água Branca e da rua Itapicurú (no trecho hoje denominado rua Turiaçú), até o bairro da Água Branca (de onde partia a estrada para a veneran'dia Freguezia do 0 ) e à nascente Lapa; no rumo do Norte, através da rua dos Voluntários da Pátria, que ia ter ao pequenino núcleo de Sant'Ana, à margem direita do Tietê; em direção do Leste, através d'a então Avenida da Intendência (atual Celso Garcia), em busca do isolado e pequeno núcleo da Penha; no rumo de Sudoeste, através de um simples caminho carroçável, de que resultou a atual avenida Rebouças, a qual alcançava a "Vila dos Pinheiros". Já arruados, embora pouco habitados e ainda isolados da cidade, apareciam o Ipiranga e Vila Prudente.

Todavia, grandes espaços vazios continuavam a existir, separando as zonas mais densamente ocupadas, em plena cidade. Assim acontecia no início de rua Augusta e vizinhanças, no trecho entre as ruas Santo Amaro e Frei Caneca, entre a Avenilda Brigadeiro Luis Antônio e a Liberdade, como também no Cambucí. Correspondem a áreas de topografia movimentada e irregular, onde se situam as cabeceiras de ribeirões afluentes da margem esquerda do Tamanduateí (como o Lavapés, Anhangabau, Saracura, etc.). De um modo geral a cidadie continua a formar blocos que dão a idéia de várias pequeninas cidades sucessivas e sucessivamente agrupadas, dentro de um perímetro constituido por uma periferia instável, dado que se expande die olhos vistos.

"São Paulo não é uma grande cidade (Grossstadt), mas um amontoado de pequenas cidades construidas uma ao lado da outra e uma dentro da outra, um acidade que está em vias de se transformar em cidade grande" (43). Essa foi a impressão de Hesse-Wartegg na época. E o mesmo autor que, mais adiante, continua: "Tudo transpira o estado inacabado e a grandeza futura, até os homens, pois as relações sociais ainda são confusas, turvas,

(41). - GAFFRE (L.A.). obra cit., pág. 160.

(42). - GAFFRE (L.A.), cbra cit., pág. 160

(43). - HESSE - WARTEGG, obra' cit., pág. 149. 
as águas ainda não clarificaram, os sedimentos ainda não se depositaram no fund'o, as camadas ainda não se formaram" (44).

Percebe-se, por outro lado. que dois fatôres da natureza econômica presidiram a expansão urbana: de um lado, a riquesa proveniente do café fazendo nascer as bairros residenciais finos; de outro lado, o desenvolvimento industrial estimulando o crescimento d'os bairros da área do Brás e vizinhanças.

Salvo êsses bairros industriais e operários, fixados na parte baixa da cidade, os outros deram preferência aos tôpos das colinas e aos espigc̃es; neste particular, a Avenida Paulista pode ser considerada um verdadeiro símbolo, pois se instalou exatamente no Espigão Central, divisor das bacias do Tietê e Pinheiros.

O próprio vale do Anhangabaú, em pleno centro da cidade, continuava sem urbanização, que só se completou na segunda décadła do século atual.

Dentro, ainda, da primeira década do século $\mathrm{XX}$, registrou-se o que poderiamos denominar de terceira fundação da cidade. em virtude de razões idênticas às que levaram Simões de Paula a referir-se a uma "segunda fundação" (44). Na realidade, sob a administração dos prefeitos Antônio Prado e Raimundo Duprat, passou a cidade por tais transformações urbanísticas e recebeu tais melhoramentos, que somos levados a compará-los aos realizados durante a presidência de João Teodoro (46). Tais fatos justificam, por isso mesmo, as referências lisonjeiras feitas pelos estrangeiros que nos visitaram, por essa época:

Na verdade, ao mesmo tempo que Francisco Pereira Passos e Osvaldo Cruz faziam aparecer um novo Rio de Janeiro, com amplas vias públicas e livre de endemias, um fato idêntico se verificava na Paulicéia: executaram-se vastas e custosas obras de saneamento, :sobretudo na várzea do Tamanduateí; canalizaram-se os rios e ribeirões da cildade; garantiu-se, para a população, melhor e maior quantidade de água potável; rasgaram-se novas ruas e avenidas; ajardinaram-se as praças e pavimentaram-se, da melhor maneira possível, as ruas da parte principal da cidade. Disso tudo resultou uma nova cidade de São Paulo, bem diversa daquela que nos havia legado o século XIX.

(44). - HESSE - WARTEGG, cbra cit ., pág. 151.

(45). - PAULA (E. Simōes de), Contribuição monográfica para o estudo da seğunda fundação de São Paulo. São Paulo, 1936.

(46). - Ainda muito recentemente, escreveu o eng. FRANCISCO PRESTISS MAIA: "Pode-se dizer que a cidade teve quatro surtos urbanísticos de importância crescente. O primeiro, por volta de 1875, no govêrno Joāo Teocioro. O segundo, no início do século, na administração Antônio Prado. O terceiro, envolvendo já apre ciável transformação central, na administração Duprat (1911). O quarto. no período 1938-1945. quando foi tentada uma remodelaçäo mais radical e sob critérios gerais de coorćenação" (em: São Paulo, álbum. com fotografias coloridas, de KURT P. KARFELD, ed. Melhoramentos, São Paulo, 1954). 
"Tal como a Capital Federal, escreveu Marie Wright, exatamente nesse período -, São Paulo transformou-se em poucos anos; e, embora a mudança não tenha sido tão rápida nem tão radical como no Rio, aparece com suficiente importância para deixar sua marca em muitos trechos do velho São Paulo imperial, o qual ràpidamente se transformou no moderno São Paulo republicano" (47). Tanto ela. como Manuel Bernárdes (48) e Paul Walle (49), fazem encomiásticas referências à administração do Conselheiro Antônio Prado, que se prolongou por dez anos, a partir de 1898. Além de obras de saneamento, que fizeram de São Paulo "una de las ciudades más sanas del mundo", (50) deve-se a êle a abertura da Avenida Tiradentes, o aformoseamento do Largo de Paissandú e o ajardinamento, ainda hoje existente, da Praça da República. Em 1905, recebeu uma grandiosa manifestação popular e foi inaugurado seu busto em bronze, na Câmara Municipal, para atestar "aos vindouros o culto do Dever e a valorosa dedicação do administrador modêlo" (51).

Nos anos que se seguiram, até findar-se o primeiro quartel do presente século, prosseguiu a expansão da ciđade.

De início, ampliou-se a área do Belenzinho e da Mooca, graças aos três fatôres conjugados: o desenvolvimento industrial, as correntes imigratórias e a presença da via-férrea. Passou a ser inteiramente ocupado o espigão de Vila Mariana, no Paraíso. Na Avenida Paulista, os vazios foram preenchidos e novos palacetes vieram atestar o progresso econômico 'da cidade. Os paulistanos continuavam a dar preferência aos trechos mais elevados. Ampliou-se o bairro das Perdizes, que passou a se unir ao da Água Branca, embora por estreita faixa edificada. Também a Ponte Grande, graças à Avenida Tiradentes, passou a integrar-se definitivamente na área urbana. A expansão da cidade não se fêz, apenas, pelo aumento de seu perímetro: adensou-se o casario nas áreas já anteriormente ocupadas e. sobretudo, foram preenchidos os claros até então existentes no interior da cidade.

Escrevendo em 1920, Roberto Capri caracterizou, com sua abundante adjetivação, alguns dos lograd'ouros da cidade: o Brás era "o pulmão industrial" da metrópole; a Avenida de São João, "extensa e borbulhante"; a Avenida Angélica, "quieta e suave"; a Avenida Higienópolis, "aristocrata e grave, de construções solenes"; e a Avenida Paulista, "Ampla, rendezrvous do povo chic, com seus palácios fidalgos, com o Belvedere" ... "onde, em ágapes distintos, reune-se

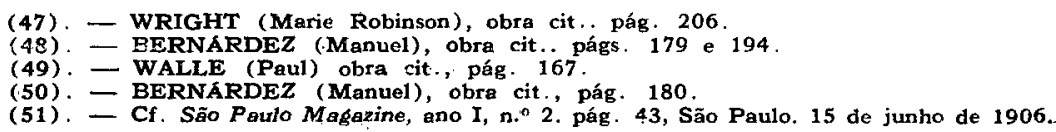


a. nossa nobreza intelectual". A vida noturna seria intensa, girando em tôrno dos teatros (Municipal, São José, Sant'Ana, Colombo) e nos "cinemas borbulhantes de gente" (Central, Royal, Avenida, Colombio) (52).

Por volta de 1925, finalmente, pode ser assim delimitada a área urbana (53):

a) um bloco compactamente edificado, limitado ao Norte pelas vias-férreas, a Leste pelo vale do Anhangabaú, a Oeste pelo vale do Pacaembú e ao Sul pelo espigão da Avenida Paulista;

b) uma área compactamente edificada, a Leste do Tamanduateí, compreendendo o Brás, a Mooca e o Belenzinho, a qual é cortada em três pontos por estradas de ferro;

c) uma área pequena, porém populosa, situada na várzea, 20 norte das linhas férreas, compreendendo o Bom Retiro, a Luz e a Baixa Casa Verde;

d) uma área a oeste do vale do Pacaembú, compreendendo Perdizes, Vila Pompéiea, Água Branca, Lapa e o início do Alto da Lapa;

e) uma zona de bairros novos, situados nas vizinhanças do Tietê (margem esquerda) e de colina da Penha;

f) o Ipiranga, então bairro-subúrbio, instalado parte na várzea e parte nas vertentes do Tamanduateí;

g) uma zona irregular, nuclesda pelo centro da cidade, entre o vale do Anhangabaú e a Aclimação;

h) a zona localizada a Sudeste do espigão da Avenida Paulista, compreendendo Vila Cerqueira César, Pinheiros, Vila América e Jardim América;

i) uma zona situada ao .Sul da Avenida Paulista, constituida principalmente pela Vila Mariana;

j) uma pequena área ao Norte do Tietê, com o antigo núcleo de Sant'Ana.

Como se vê, São Paulo era ainda uma cidade fracionada, constituida por trechos edificados separados uns dos outros, ora por obstáculos naturais (como é o caso das várzeas e dos vales mais escavados), ora pela presença das vias-férreas.

Exatamente nesse período, um novo elemento foi acrescentado à fisionomia da cidade; os bairros-jardins, introduzidos a partir de 1915 e multiplicados na terceira década do século. Viriam

(52) - CAPRI (Roberto), São Paulo, a Capital Artística, na comemoração do Centenbrio, São Paulo, 1922.

(53). - Consulte-se a Planta da Cidado de São Paulo, organizada por V.ALDOMIRO GONÇALVES. São Paulo. 19.24 - Bruno Antônio Voci - "Transporte coletivo na ciciade de São Paulo". 
a tornar-se, mais tarde; alguns dos bairros mais elegantes e bonitos da cidade atual, como o Jardim América, o Jardim Europa e o Pacaembú.

Coube à Companhia City, de capitais ingleses, iniciar a cons trução dos bairros-jardins em São Paulo, a partir de 1915. Antes da primeira Grande-Guerra, comprou essa emprêsa extensas áreas de terrenos nas zonas urbanas, investindo desde logo importantes somas em obras de terraplanagem, arruamentos e pavimentação. Já em 1916, achava-se completamente arruado o Jardim América; e outros se lhe seguiram: Jardim Europa, Pacaembú, Alto da Lapa, Bairro Siciliano e Alto de Sant'Ana (54).

\section{O CRESCIMENTO DE SÃO PAULO ATE 1925 E OS PROBLEMAS QUE ACARRETOU.}

Como é de se esperar, ao mesmo tempo que se processava a expansão da área urbana, nesse primeiro quartel do século $X X$, tinha lugar o crescimento da população paulistana.

No período focalizado, realizou-se apenas um recenseamento: o de 1920, que deu para o município uma população de 579:033 habitantes, o que significa que aumentou mais de duas vezes, numa vintena, a exemplo do que já acontecera no período de 1870-90. No entanto, o ritmo de crescimento foi menor que o da década final do século XIX ,quando a população quadruplicara, por haver sido êste o período áureo da imigração européia.

Afora aquela cifra da população efetivamente recenseada, encontramos estimativas para vários anos (55):

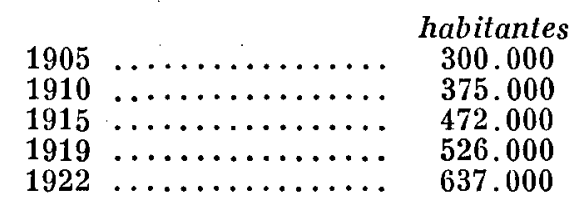

Percebe-se, assim, que a cidade, teve um aumento médio de 70.000 habitantes nos dois primeiros quinquênios; ao passo que tal aumento passou a ser de 100.000 nos dois quinquênios seguintes. Explica-se o fato pelo declínio da imigração, no decorrer da primeira década do século, em virtude de sensível diminuição da entrada de italianos e dos numerosos retornos verificados. O movimento imigratório no Estado chegou a ser quase deficitário:

(54). - SARAIVA (Amacieu de Barros). As recentes criaçöes urbanas em São Paulo, em "Arquitetura no Brasil", vol: V: n: 29, págs. 176-181, Rio, Junho-julho de 1926.

(55). - Cf. PAULO RANGEL PESTANA, Em São Paulo, a Capital Artísticaj'na comemeração do centenário. 1922; e EGAS (Eugênio), "Os Municipios Paulistas" São Paulo, 1925. 
no periodo de 1900-1907, entraram 308.809 imigrantes e sairam 277.029 ! (56).

No terceiro quinquênio (1910-1915) novamente a imigração retomou seu antigo ritmo, graças à resolução da crise da imigração italiana, à melhoria da situação da lavoura cafeeira e ao crescente desenvolvimento industrial. Eis algumas cifras (57):

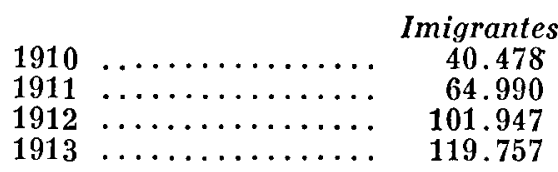

De qualquer maneira, pode-se afirmar que São Paulo alcançara a população de 800.000 habitantes ao findar o primeiro quartel do presente século, firmando cada vez mais sua bela posição de segunda cidade brasileira e deirsando longe, em sua marcha ascencional, es demais capitais de Estado. Já era a terceira cidade da América do Sul, ultrapassando Montevidéu e Santiago do Chile; alinhava-se ao lado de Roma e de Colônia (58).

Essa bela posição não fai alcançada apenas pelo gênio progressista dos paulistas, sua habilidade prática e seus enérgicos empreenđimentos - como pensava Marie Wright (59); ou porque houvesse "something in the air of São Paulo which makes strong and vigorous men", conforme a frase de Elihu Root. Também não se deve exclusivamente à contribuição do elemento estrangeiro, que continuou estrangeiro, que continuou a ser sempre numeroso na cidade, embora em menores proporções e não apenas italianos, como no comêço do século; portuguêses e espanhois vinham à frente das correntes imigratórias, logo seguidos pelos italianos, e um elemento novo apareceu - o imigrante japonês (61). Todos êsses fatôres, a par da crescente prosperidade econômica, então já assegurada pelo binômio café-indústria, concorreram para criar condições inteiramente favoráveis ao cresicimento vegetativo. $\mathrm{Na}$ verdade, em todo o período que vimos focalizando, a taxa de natalidade é, em média duas vêzes mais elevada que a da mortalidade.

De acôrdo com os dados obtidos por Paulo Rangel Pestana (60), assim se caracterizaram a natalidade e mortalidade na capital paulista, na primeira vintena do século :

(56). - Cf. AzEVEDo (Sálvio Almeida), Imigração e Colonização no Estado da São Paulo. pág. 121, em "Revista do Arquivo Munipal". vol. LXXV. São Paulo, 1941 .

(57). - Cf. AZEVEDO (Sálvio Almeida), obra cit.. págs. 126-127.

(58). - Cf. CAPRI (Roberto), Sãa Paulo, a Capital Artistica, pág 34.

(59)..- WRIGHT (Marie Rcbinson). obra cit., pág. 205;

(60). - Cf. WRIGHT (Marie Robinson), obra cit., pág. 205

(61). - Cf : AZEVEDo (Sálvio Almeida), obra cit., págs. 120-127. 


\begin{tabular}{|c|c|c|c|c|}
\hline & \multicolumn{2}{|c|}{ Natalidade } & \multicolumn{2}{|c|}{ Mortalidade } \\
\hline & Nascimentos & $\operatorname{tax} a$ & óbitos & $\operatorname{tax} a$ \\
\hline $\begin{array}{l}1900 \\
1910 \\
1919\end{array}$ & $\begin{array}{r}8.684 \\
12.287 \\
16.916\end{array}$ & $\begin{array}{l}36,02 \% \\
32,73 " \\
32,13 "\end{array}$ & $\begin{array}{l}4.537 \\
6.246 \\
9.995\end{array}$ & $\begin{array}{l}18,91 \% \\
16,64 \text { “ } \\
18,96 \text { “ }\end{array}$ \\
\hline
\end{tabular}

A queda verificada no ano de 1919 explica-se pelo elevado coeficiente de mortalidade infantil, então registrado, em virtude da gripe, do sarampo, da escarlatina e da coqueluche, que se fizeram sentir com 'desusada virulência. Cumpre, ainda, assinalar que a gripe espanhola, em 1918, fêz 5.372 vítimas na capital paulista (61).

São Paulo continuava a ser uma cidade cosmopolita. Predominavam os europeus, um grande número dos quais e seus descendentes tinham já um bom padrão de vida (64). De acôrdo com Paul Walle, com base nas cifras de natalidade e na nacionalidade dos pais dos recém-nascidos, formariam, por volta de 1910, nada menos de dois terços da população da cidade (65).

São Paulo deixara de ser "a cidłade de italianos", que Alfredo Moreira Pinto conhecera, em 1900 (66). Mas o elemento peninsular, como é natural, continuava a representar um papel de muita importância, não apenas na massa da população, como nas atividades urbanas e na própria fisionomia da Paulicéia (67). A seu lado, em sensível minoria, apareciam os elementos ibéricos, além de sírio-libaneses e japoneses. Nos anos imediatamente posteriores à primeira Grande-Guerra, novos contingentes chegaram, insatisfeitos com as conseqüências do após-guerra: húngaros e povos do Báltico. Tudo isso, sem falar nos elementos germânicos e anglosaxões. Pierre Denis admirou-se com a capacidade de assimilação do elemento alienígena por parte de São Paulo: "Por sua atividəde e por sua energia, São Paulo tem um poder de absorção relativo aos imigrados que não se encontra, no mesmo gráu, em nenhuma outra região brasileira" (68).

De acôtdo com Roberto Capri, em 1912 os italianos eram proprietários de 32 milhões de pés de café, produziam 425.000 sacas e possuiam 23.520 propriedades urbanas (69).

\footnotetext{
(62). - E. CAPRI (Roberto), São Paulo, a Capital Artística.

(63). - Cf, PESTANA (Paulo Rangel), em São Paulo, a Capital Artística.

(64). WALLE (Paul), obra cit., pág. 174

(65) - WALLE (Paul), obra cit., pág. 174

(66): - PINTO (Alfredo Moreira), A Cidade de Sãa Paulo em 1900 (Impressōes de viagem), Imprensa Nacional, Rio, 1900.

(67). - Consulte-se as obras de M. BERNARDES, P. WALLE R, CAPRI, e DEBE NEDETTI (E.) e SALMONI (A.). architettura Italiana, San Paolo, eci. di Instituto Cultural Italo-Brasileiro, S. Paulo, 1953.

(68). - DENIS (Pierre), Amérique du Sưd, tômo XV, 1.a parte. pág. 189. Liv. Armand Colin, Paris, 1927

(69) . - CAPRI (Roberto), O Estado de São Paulo e seus Municípios, págs, 16-17
} 
A expansão d’a área urbana e o crescimento demográfico repercutiram. naturalmente, no ritmo das construções urbanas $\mathrm{Na}$ primeira década do século, o número de prédios passou de 21.656; em 1900, para 32.914, em 1910, o que significa um aumento de mais de 10.000 prédios, isto é, cêrca de mil por ano. Ao terminar . segunda década ,o total já atingia quase 60.000 , o que corresponde a um aumento três vezes maior ao registrado no período anterior, com a média anual de 3.000 prédios (70).

Eis uma estatística expressiva, referente ao número de prédios segundo os distritos (71).

\section{$1911 \quad 1918$}

\begin{tabular}{|c|c|c|c|}
\hline Sé & 1.128 & & 1.434 \\
\hline Santa Ifigênia .... & 5.874 & $\ldots \ldots$ & 4.827 \\
\hline Consolação ...... & 5.885 & $\ldots \ldots \ldots$ & 4.719 \\
\hline Brás . . . . . . & 8.058 & $\ldots \ldots$ & 5.365 \\
\hline Mooca $\ldots$. & & & 7.183 \\
\hline Santa Cecília .... & 5.670 & $\ldots$ & 6.216 \\
\hline Bom Retiro ..... & - & & 2.836 \\
\hline Liberdade $\ldots . \ldots$ & 4.160 & . & 5.185 \\
\hline Bela Vista & - & . & 3.874 \\
\hline Belenzinho & 2.120 & $\ldots \ldots$ & 5.370 \\
\hline Vila Mariana .... & 1.478 & $\ldots \ldots \ldots$ & 3.403 \\
\hline Cambucí $\ldots \ldots \ldots$ & 165 & $\ldots \ldots \ldots$ & 1.390 \\
\hline$\ldots \ldots \ldots$ & - & $\cdots$ & 2.221 \\
\hline Sant'Ana & 651 & $\ldots \ldots$ & 1.707 \\
\hline Penha. & 353 & & 478 \\
\hline 101 & 36.128 & & \\
\hline
\end{tabular}

Através das próprias cifras e dos desmembramentos verificados (em 1911, Mooca, Bom Retiro, Bela Vista e Lapa ainda não eram distritos autônomos), pode-se sentir o crescimento e a expansão da cidade, impressionante em alguns setores, embora lento noutros.

Essas habitaçóes ofereciam contrastes chocantes. Perduravam, ainda, muitas casas e uns poucos sobrados construidcs de taipa, herança do passado. Na área central, notavam-se já alguns prédios altos, embora a maioria não tivesse mais do que um ou dois andares, a exemplo dos que existem até hoje, sobretudo nas vizinhanças da Praça da Sé. Datam dêsse período o ajardinamento do vale do Anhangabaú, o alargamento da rua Líbero Badaró e os melhoramentos introduzidos na Praça do Patriarca e na Praça Ramos de Azevedo; ergueram-se os palacetes Prates, um dos quais ainda resta, abrigando a Câmara Municipal. Canalizado o Tamanduateí (1914) e saneada a Várzea do Carmo, surgiu ali o Parque Dom Pedro II.

(70). Cf. PaUlo R. PESTANa, loc. cit.

(71). - Cf. PAULO R. PESTANA, nas obras publicadas por.R. CAPRI. 
Nos bairros, predominavam as habitações de aspectos modestos, de um só pavimento, geralmente possuindo poróes, dando diretamente para a rua e obedecendo a um estilo mais ou menos padronisado, sem nenhum encanto arquitetônico; assim eram as moradias da classe média e da população operária, de que perduram numerosos exemplos, notadamente na Bela Vista, em Vila Buarque, em Santa Ifigênia, na Barra Funda, no Bom Retiro e no Brás. Em. contraposição, nos bairros aristocráticos predominavam as grandes, mansões senhoriais e os ricos palacetes dos milionários do café e "capitães da indústria" da Paulicéia d'e então; ainda hoje podemos. admirá-los, embora alguns se encontrem em plena decadência: as fidalgas residências de Elias Chaves (atual Palácio dos Campos

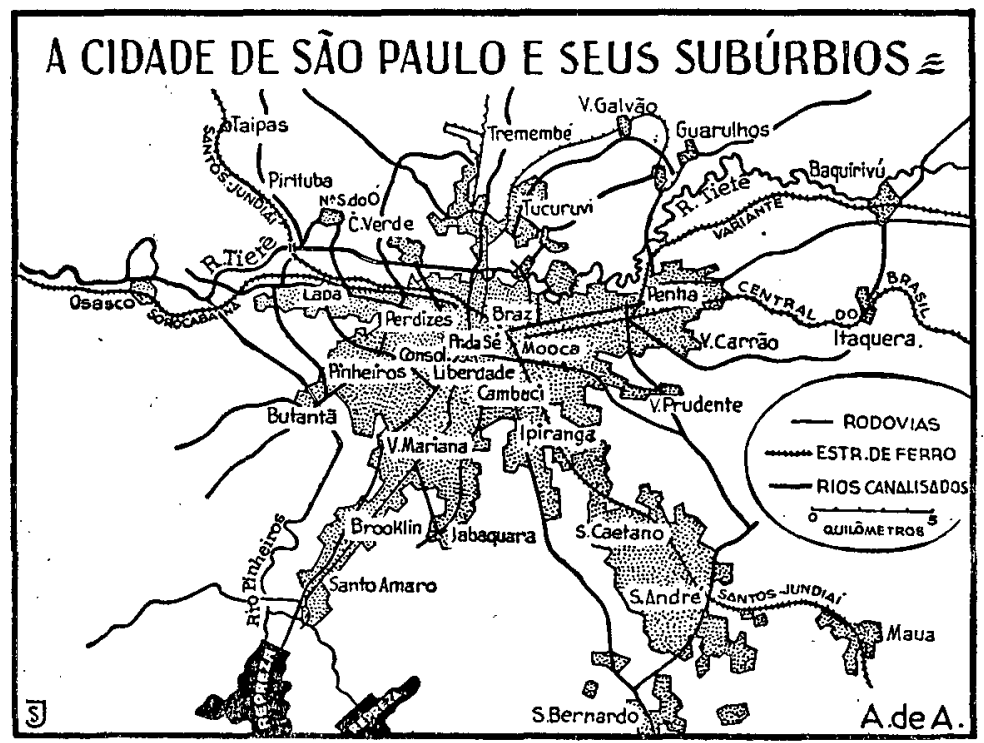

Apud Aroldo de Azevedo, Subúrbios de São Paulo e suas funçôes.

Elíseos) e do Conde de Prates, no bairro dos Campos Elíseos; as. admiráveis mansões da Avenida Higienópolis, entre as quais se: destacavam a "Vila Veridiana" (residência do conselheiro Antônio Prado) e o palacete do Conde Álvares Penteado, onde hoje se acha instalada a Faculdade de Arquitetura e Urbanismo; e tantas outras, construidas na Avenida Paulista.

Ao findar o primeiro quartel do século atual, São Paulo era, ainda, uma cidade baixa, que muito pouco crescera no sentido vertical e só excepcionalmente conhecia prédios de seis e sete andares. 
A êste propósito, são significativos os dadios numéricos que se seguem (72):

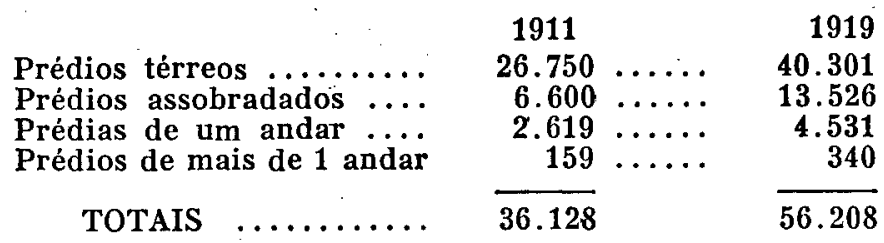

Todavia, tais: cifras atestam inequívocos sinais do crescimento vertical que haveria de caracterizar o segundo quartel do século, embora apenas no que concerne aos prédios assobradados e de mais de um andar. Com efeito, tal fato aparece melhor quando examinados as porcentagens:

$\begin{array}{lrlll} & & 1911 & & 1919 \\ \text { Prédios térreos } \ldots \ldots \ldots \ldots \ldots & \mathbf{7 4 \%} & \ldots \ldots & \mathbf{7 1 \%} \\ \text { Prédias assobradados } \ldots \ldots \ldots & 18 \% & \ldots \ldots & \mathbf{2 4 \%} \\ \text { Prédios de um andar } \ldots \ldots \ldots & 7 \% & \ldots \ldots & 12 \% \\ \text { Prédios de mais de um andar } & 0,4 \% & \ldots \ldots & \mathbf{0 , 6 \%}\end{array}$

A maioria das novas construções, tanto as residências finas como as da classe média, trazia a marca da arquitetura italiana, em estilo neo-clássico ou florel; e os próprios edifícios públicos, construidos nessa época, sofreram, como é natural, essa influência (73). A êsse respeito eis o que nos diz Bartolotti:: "Os bairros elegantes concentram-se em uma zona de luxuriante vegetação tropical estupendamente combinada à delicada flora das regiões tropicais, de onde surgem elegantes villini, graciosos palacetes e mesmo soberbas ville, em uma variedade de côres (tinte),. e de formas arquitetônicas tais, que se a primeira vista dão a impressão de uma confusão (izialdone) de estilos demonstram todavia, um bom gôsto artístico regra geral de marca (d'intonazione) italiana (74).

O Teatro Municipal, por exemplo, construido entre 1908 e 1911, foi arquitetado por Ramos de Azevedo com a colaboração de Domiciano e Cláudio Rossi. Antes disso, o mesmo escritório de engenharia havia construido o edifício da antiga Escola Normal (atual Instituto de Educação "Caetano de Campos), inaugurado em 1908, dentro das linhas do neo-clássico italiano.

(72). - Cf. PAULO RANGEL PESTANA em O Estado de São Paulo e seurs Municípios (ed. de Roberto Capri, 1913), pág. 82; e A Capital Paulista comemorando - Centenário da Independência, ed. em 1920.

(73). - Consulte-se, sôbre o assunto, DEBENEDETTI (E.) e SALMONI (A.), obra

(74) - BARToLóTTI, Domenico, II Brasile Meridionale. Alberto Stock. Roma, pág. 204. 
Muitos problemas urbanos tiveram feliz solução durante essá fase 'd'a evolução da cidađe; assim, a iluminação pública è particuler,: a pavimentação, o serviço de águas e esgotos, os transportes.

De início, a maioria das ruas paulistanas era iluminada a gás, embora a área central já conhecesse os benefícios da luz elétrica. Sòmente a partir de 1922 registrou-se a expansão da iluminação elétrica, no conjunto da cidade. Dái o aspecto algo provinciano e tristonho que São Paulo apresentava à noite, no decorrer de todo êsse período; daí a importância daquele personagem urbano, hoje desaparecido - o acendedor de lampeões, que pontualmente a percorria ao anoitecer.

Em 1907, existiam na cidade 4.558 combustores de gás; ém 1915, êste número elevou-se para 9.396, o que correspondia a dez vêzes o de focos elétricos; e, em 1922, atingiu 10.031 (75).

Sòmente a partir de 1916, a Light passou a fornecer luz elétrica às vias públicas; por isșo mesmo, antes disso, era reduzidissimo o número de focos elétricos (em 1914), apenas 846). Entretanto, já em 1920, êsse total elevava-se a 2.153 e, dois anos mais tarde, a 2.661 , isto é, menos de um quinto dos combustores de gás. A partir de 1922 a expansão da luz elétrica prosseguiu em marcha acelerada, substituindo a iluminação a gás, que veio a desaparecer pouco depois de 1930 .

A iluminação elétrica deu vida nova à cidade. Mesmo bairros distantes viram-se beneficiados: é o caso da Ãgua Branca, Lapa, Ipiranga e Penha que, já em 1912, possuiam alguns focos elétricos. De um modo geral, dava-se preferência ao centro da cidade, às ruas dos melhores bairros e aos locais de recreação. Em 1915, iluminou-se o. Miradouro (Trianon) da Avenida Paulista; em 1916, todo o "Triângulo", a esplanada do Teatro Municipal e os relógios públicos passaram a ser iluminados por luz elétrica. Em 1918, a Avenida Paulista recebeu novos focos e o mesmo benefício extendeușe ao vale do Anhangabaú, à Bela Vista e ao Largo da Concórdia (Brás). Em 1922, chegou a vez do Jardim América, de Sant'Ana e do Ipiranga .

A pavimentação das ruas e praças recebeu um grande impulso na administração do prefeito Antônio Prado, que elevou êsse benéfício a um total de um milhão de $\mathrm{m}^{2}$, o que fez com que cada habitante da cidade passasse a dispor de $5,40 \mathrm{~m}^{2}$, quando, na mesm época, cada habitante de Buenos Aires só dispunha de $6,45 \mathrm{~m}^{2}(76)$. Utilizava-se o macadame e paralepípedos de granito. Em 1921,

\footnotetext{
(75). - Cf. EgAS (Eugênio), Galeria dos Presidentes do Estado de São Paulo, vols. II e III, São Paulo, 1927.

(76), - BERNARDEZ (Manue1), obra cit., pág. 194
} 
a área calçada da cidad'e tinha uma superfície de $2.740 .000 \mathrm{~m}_{3}^{2}$ (77).

O serviço de águas e esgotos não conseguia alcançar o ritmo acelerado do crescimento urbano. Foi também na primeira décadá do século que a cidade passou a ser mais bem servida de água, graças à utilização de mananciais d'a Serra da Cantareira e do rio Cotia. Todavia, registravam-se muito contrastes de um bairro para outro, o mesmo acontecendo com a rêde de esgotos.

Em 1905, 22.889 prédios eram abastecidos de água, numa rêde total de 392.867 metros. Em 1908, tais cifras haviam pas; sado, respectivamente, para 26.370 e 416.336 .

No que se refere à rêde de esgotos, em 1903 existiam 20.074 prédios beneficiados; ao passó que, em 1908, êste número subiu para 24.270, numa rêde total de 874.548 metros. Por essa época;, Vila Mariana, Perdizes, Água Branca, Lapa e Belenzinho não gosavam dessa vantagem; Cambuci, Mooca, Bom Retiro, Barra Funda e Higienópolis eram servidos de maneira incompleta.

Nos anos seguinteș, a șituação foi sempre melhorando, conforme se pode constatar pelos dados abaixo:

$$
\text { Agua } \quad \text { Esgotos }
$$

\begin{tabular}{|c|c|}
\hline $1911 \ldots$ & 449.793 \\
\hline [6-1917 & $\begin{array}{l}598.414 \\
660880\end{array}$ \\
\hline
\end{tabular}

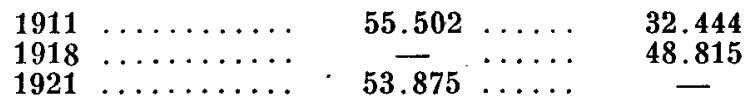

Cumpre assinalar que, em 1912, foram concluidas as rêdes de esgotos das vertentes do Tamanduateí em Vila Mariana e no Cambuci e iniciadas as rêdes das Perdizes e de parte do Ipiranga que, se concluiram em 1914. Em 1915, estavam terminadas as rêdes da Barra Funda e do Bom Retiro, dando-se início às da Água Branca, Lapa e Sant'Ana. Em fins de 1922, iniciaram-se os serviços para o prolongamento da rêde de esgotos desde a Alameda Santos até o Jardim América e a Vila Cerqueira César (78).

Em relação aos transportes urbanos, as primeiras linhas de bondes elétricos (de cujo serviço era concessionária a Light) foram inauguradas em 1900, pondo o centro da cidade em comunicação com a Barra Funda, a Vila Buarque e o Bom Retiro; mas os bondés

(77). - EGAS (Eugênio), Os Municípios Paitilistàs, vol. I, pág. 476.

(78). - Cf. EGAS (Eugênio), Galeria dos Presidentes do Estado de São Paulo, , 
de tração animal e algumas linhas a vapor (para Santo Amaro e pra a Cantareira) continuavam a servir a cidade (79). Durante todo o período que vimos focalizando, entretanto, são os veículos de tração animal que predominam no tráfego urbano, particularmente as pequenas carroças de duas rodas (largamente utilizadas no serviço de passageiros). Os automóveis não passariam, ao findar o primeiro quartel do século, de pouco mais de 2.500 .

A rigor, os primeiros bondes elétricos começaram a circular a partir de 1897; mas, só depois de 1900 foi que se estabeleceram as linhas de maior extensão.

Em 1908, os bondes da Light transportaram 24.981.106 passageiros e o Tramway da Cantareira conduziu 277.629. Dez anos mais tarde, símbolo do crescimento demográfico da cidade, os primeiros transportaram 58.455.792 passageiros e o segundo 1.730.941. Neste mesmo ano de 1918, assim se distribuiam os automóveis (80).

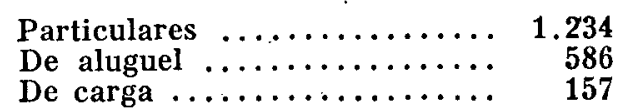

Em 1921, a Light tinha em serviço 407 bondes para passageiros, havendo transportado nada menos de 103.938.584 pessoas, o que é realmente notável, pois significa quase o dôbro da cifra registrada três anos antes. (81).

Muito expressiva é a relação discriminada dos veículos urbanos, mencionada por Eugênio Egas (82), que vamos aqui sintetizar de acôrdo com os respectivos grupos:

a) Veículos de tração animal:

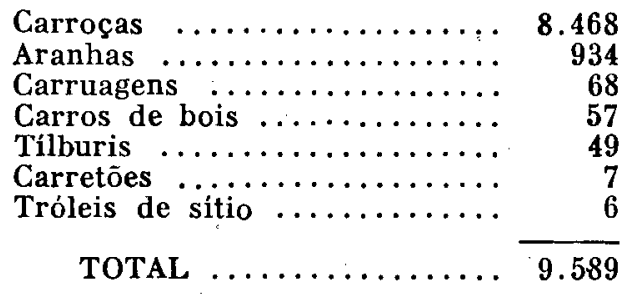

b) Veículos motorizados:

\footnotetext{
(79). - Cf. Cinqüenta anos de progresso com São Paulo (1900-1950), publicação de "The São Paulo Tramway, Light and Power Co. Ltd."

(80). - Cf. A Capital Paulista comemorando o Centenário da Independência, dados de PAULO R. PESTANA;

(81). - Cf. EgAS (Eugênio), Os Municípios Paulistas, I, pág. 479.

(82). - Cf. EGAS (Eugênio), Or Municípios Paulistas, I, pág. 477.
} 


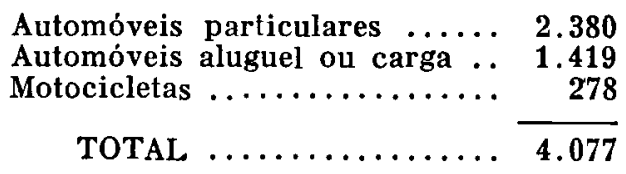

c) Outros veículos:

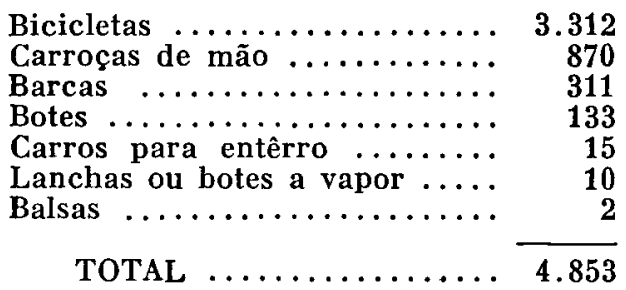

Isto significa que, num total de 18.519 veículos, mais de $\mathbf{5 1 \%}$ eram movidos por tração animal. Pormenores interessantes há a registrar, neste particular: entre as carroças, 1.039 destinavam-se ao transporte de pão ou leite, 1.160 ao transporte de lenha ou hortaliças, e 45 ao de carne; entre as carruagens, 67 eram de aluguel e 65 tinham rodas de borracha; e entre os tílburis (ainda os havia há vinte e cinco anos atrás!) 45 eram de aluguel. Note-se, outrossim, o número elevado de aranhas e, naturalmente correspondendo à zona rural, os carros de bois e os tróleis.

Os veículos motorizados correspondiam a sòmente $20 \%$ do total. Quanto aos demais, observa-se que o número de bicicletas era superior ao de automóveis particulares e que não era despresível o número dos que se destinavam à navegação fluvial (num total de 456).

O fenômeno que já se esboçara na segunda metade do século XIX, como conseqüência da expansão da área urbana, acentuou-se definitivamente no primeiro quartel do século XX: a cidade passou a possuir áreas funcionais mais ou menos bem definidas.

O velho centro caracterizava-se inteiramente como zona comercial, sobretudo do comércio varejista, ao mesmo tempo que o comércio atacadista passava a instalar-se nas vertentes do Tamanduateí, junto à colina histórica, e na própria várzea. Fora daí, o comércio se desenvolveu nos bairros, en determinadas ruas ou constituindo pequenos núcleos bem caracterizados.

Não nos é possível examinar em detalhes a função comercial dla cidade, nessa época, pois não teríamos espaço para tanto. Sendo uma grande cidade, com 800.000 habitantes, dispunha de elevado número de casas comerciais e, sobretudo um comércio variadíssimo, perfeitamente à altura de sua importância. "A enorme atividade comercial da praça de São Paulo - escrevia Marcelo Piza, em 1924 
- centraliza boa parte do comércio de exportação e grande parte do de importação, assim como dirige a produção agrícola, pastoril e industrial do Estado" (83).

Os trabalhos de Marcelo Piza (84) e Eugenio Egas (85) fornecem abundante material para o estudo dessa função urbana, por volta de 1921-1922. Limitarnos-emos a pôr em destaque uns poucos. mas significativos aspectos da vida comercial da Paulicéia, por essa época. E provável que existissem cêrca de 10.000 ćasas de comércio, das quais 292 dedicavam-se a artigos de importação. $O$ abastecimento alimentar era assegurado por 2.517 armazens de secos e molhados, 463 açougues, 183 quitandas e casas de frutas, 162 leiterias.. 106 confeitarias e påstelarias', etc. Havia 198 carvoarias, 183 lenharias, 219 cásas de móveis, 513 de fazendas e armarinho, $243 \mathrm{de}$. calçados, 59 de fazendas, 67 de chapéus para homens, 22 perfumarias, 36 casas de brinquedos, 86 joalherias, 32 relojoarias 62 pa-pelarias, 64 livrarias, 152 charutarias, 15 casas importadoras de automóveis, etc., além das que forneciam artigos para a indústria e materiais de construção. Resta acrescentar a existência de 30 estabelecimentos bancários.

A zona industrial da cidade, já também definida, encontrava-se localizada principalmente nos bairros de várzea, não longe das: vias-férreas, como tivemos oportunidade de acentuar. Brás, Mooca e Belenzinho eram os mais característicos. Cêrca de 2.000 estabelecimentos fabrís e 70.000 operários definiam a vida industrial da Paulicéia, ao findar o primeiro quartel do século.

Também não pretendemos estudar, nos pormenores, a função industrial da capital paulista, nessa época. Aș obras atrás citadas de Marcelo Piza e Eugênio Egas (86) contêm, neste particular, minuciosos informes. Julgamos necessário, apenas, acentuar que as in dústrias téxteis eram as mais importantes, não pelo número, mas: pela produção e mão de obra empregada: existiam 37 fábricas de tecidos de algodão, 39 malharias, 8 fábricas de tecidos de sêda, 6 de tecidos de lã, 3 de tecidos de juta, que davam trabalho para mais de 20.000 operários; e que também se destacavam: as fábricas d'e calçados, num total de 83 , as de chapéus, num total de 36, as fundições, as de produtos químicos, as serrarias, etc. Por outro lado, muito ativa continuava a ser a pequena indústria (609. sapateiros, 250 marceneiros, 124 tintureiros, etc. ).

Uma terceira área funcional - a residencial completava o quadro urbano, sob êsse aspecto. Pràticamente afastada do velho centro,

\footnotetext{
(83). - PIZA (Marcelo), Os Municípios da Estado de Săo Paulo, jág. 257, ed. Secre--

(84) taria da Agricultura do Estado de Sāo Paulo, 1924.

(84). - PIZA (Marcelo), Obra cit. págs, 257-258.

(85). - EGAS (Eugênio), Os Municípios Paulistas, I, págs . 480-481.

(86). - PIZA (Marcelo), obra cit., págs. 258-483.
} 
aparecia bem caracterizada no restante da cidade, scb a tríplice modalílade a que já tivemos oportunidade de nos referir: os bairros. da classe média, na periferia do centro e, ainda, em pontos mais ou menos afastados; os bairros operários, localizados sobretudo nas vizinhanças da zona industrial; e os bairros aristcctáticos, desde os Campos Elíseos até à Avenida Paulista e ao então nescente Jardim América. "Esta metrópole cuja descrição detalhada é cuifícil, requerendo muito espaço, pode dividir-se em três zonas - do centro comercial dos bairros elegantes e dos arrabaldes populares. $O$ centro comercial é constituido pelas três ruas principais - 15 de Novembro, São Bento e Direita - que formam o famoso triângulo no coração da cidade. São os logradouros dos bancos, das principais casas comerciais, das grandes confeitarias e casas de bebidas, das redações dos jornais, dos estabelecimentos de modas, das joalherias, etc., do mundo elegante e t'aquele dos negócios, que, porém, não se con-' fundem, o primeiro dominando sobretudo na Rua Direita, o segundo, por seu lado, recolhendo-se prevalentemente na Rua 15 de No-.. vembro.

Os bairros elegantes, onde aparecem villini, palazzine, ville, demonstram bom gôsto artístico. São as grandes avenidas, primeira: entre tốdas a Carlos de Campos, anteriormente Paulista, a ampla via asfaltada e arborizada, em uma elevação maravilhosa, onde freqüentemente escondem-se as luxuosas habitações dos ricos paulistas, em seguida, Campos Elíseos, Brigadeiro Luís Antonio, Liberdade, Higienópolis, etc., tôdas amplas com numerosas praças adornadas de jardins floriblos. Os bairros populares - Brás, Bexiga, Cambuci localizam-se longe do centro, na zona dos mais importantes estabelecimentos comerciais, onde em conseqüência, concentra-se e desenrola-se a vida do operariado" (87).

Esse rápido esquema funcional da cidade, nos primeiros 25 anos do presente século, ficaria incompleto se não fizéssemos uma referência às chamadas profissóes liberais. Os ađdvogados continuavam à frente: cêrca de 500. Numerosos também eram os médicos (410), os dentistas - 320, os farmecêuticos - 220, os engenheiros civís e arquitetos - 176. Noutras profissões, destacavam-se pelo número: barbeiros e cabeleiros - $\mathbf{8 0 5}$, as parteiras - 100, os fotógrafos - . 56 , etc. (88).

\section{A CIDADE DE SÃO PAULO NO SEgUNDO QUARTEL DO SECUlO XX.}

A partir da terceira década do século atual, ninguém poderia ter nenhuma dúvida a respeito da marcha ascencional da capital pau- -

(87). - BARDOLOTTI( Domenico), II Brasile Meridiona!le.

(88). - EGAS (Eugênio), obra cit., pág. 487. PIZA (Marcelo), obra cit, pág. 257.

(89). - DENIS (Pierre), Amdrique du Sud, 1.a parte, pág. 188, Paris, 192.7. 
lista. Debalde a crise caféeira, que se seguiu ao crack da bôlsa de Nova-York (1929), abalou em seus alicerces a economia paulista. Debalde os acontecimentos politicos, como as revoluções de 1924 e 1930 e a revolução constitucionalista de 1932, além das vicissitudes que se lhes seguiram, convulsionaram e perturbaram a vida da população do Estado. Debalde a segurida Grande-Guerra (1934-1945), em seus reflexos sôbre o nosso país, criou problemas de tôda espécie, para o seu comércio e para sua atividade industrial. Nada disso foi capaz de interromper ou, mesmo, arrefecer o ritmo de crescimento e a expansão da metrópole paulista. As estatísticas referentes a êsse período dão saltos de assombrar. Aümenta ininterruptamente sua população, amplia-se cada vez mais sua área urbana, consolida-se sua posição na liderança econômica e cultural do Estado e até do país. Um espetáculo ao mesmo tempo admirável e confortador.

Logo no início do segundo quartel do século, Pierre Denis afirmou que São Paulo "a mené la marche en avant du jeune Brésil" (89). Pela mesma época, o conde Carton de Wiart, depois de acentuar que era a cidade que constituia uma casa por hora, admirou-se de sua atividade comercial e industrial, comparando-a, neste particular, às cidades-cogumelos da América do Norte; mas sentiu nela o aspecto de uma cidade européia: fazia-lhe lembrar Lausanne, pelos seus viadutos, e Manchester ou Lyon, por suas ruas movimentadas (90). "Dans les rues, pas de promeneurs, pas de feâneurs"... (91).

Visitando-a na década de 1930-1940, um brasileiro da Amazônia - Virgínio Santa Rosa - teve, diante dos olhos, um espetáculo que o levou, certamente. a pensar nas paragens onde nasceu "As ruas extravasam gente como a torrente que deslisa na calha de um vale. Subindo ou descendo, as correntes humanas que sulcam as ruas e becos do Triângulo como que se dissolvem e quebram em pontos fixos. Sùbitamente como que desaparecem. tranquilizam-se em remansos no Largo da Sé. Praça do Patriarca, Largo de São Bento, Largo dos Correios ..." (92) Essa cidade, que faz lembrar tôda espécie de cidades e no entanto se parece com nenhuma. Talvez nessa "Chicago sul-americana "já exteriormente se manifeste, que entre o milhão de habitantes que ela conta estão representados todos os povos da Europa e ainda alguns da Ásia. Ao lado de arranha-céus inacabados, cujas rendas futuras estão em discussão, ao lado de maravilhosas avenidas com grandes palacetes, um bairro

(90). - WIART (Conde Carton de), Mes Vacances au Brésil, pág. 107, ed. Desciée

de Brouwer \& Cia., Bruges, 1928.

(9i). - WIART (Conde Carton de), obra cit., pág. 109.

(92). - ROSA (Virginio Santa), Paisagens do Brasil; pág. 109. 
comercial apertado e quase asfixiado pelo trânsito e subúrbios que lembram quarteirões proletários em qualquer lugar do Mediterrâneo (93).

Escrevendo na mesma época, Pierre Deffontaines foi sintético, mas vigorosamente exato: "São Paulo pertence, por excelência, à família das cidades de energia" (94). E um norte-americano, profundamente enraizado no país - Benjamim Hunnicutt - chamou-a de "cidade dinâmica" (95).

"No centro de São Paulo, no Triângulo - afirmou Wolfgang Harnisch - a vida pulsa numa atividade e num ritmo pouco tropical. Nessas ruas estreitas, de edifícios altos, os homens correm e se acotovelam como em qualquer capital da Europa. Nos seus rostos vemos estampada a mesma expressão de fadiga e intensidade". E conclui: "Aqueles que andam pelas ruas, que olham e gritam e vendem - sentem que alí está o centro de uma metrópole moderna, internacional de uma cidade de comércio e indústria" (96). Dentro da mesma ordem de idéias e referindo-se à mesma época, o general Lima Figueiredo chamou São Paulo "a capital do progresso" (97).

São depoimentos valiosos porque, correspondendo todos êles à mesma fase da evolução da cidade, coincidem de maneira impressionante, como se houvessem saido da mesma pena. Mais ainda: foram escritos por homens cultos das mais diversas categorias ou especialidades - geógrafos, um diplomata, simples viajante, um educadior, uma alta patente do Exército; e sobretudo, de nacionalidade diferentes - franceses, um norte-americano, um belga dois alemães, brasileiros de regiōes diversas.

Mas, afinal que tipo de cidade veio a se formar em tôrno do núcleo quinhentista criado pelos padres da Companhia de Jesús, e sôbre as bases, tão mais amplas, da "capital dos fazendeiros"? Como caracterizar, em sua fisionomia urbana, o São Paulo surgido no derradeiro meio século?

Poderá ser comparado a uma cidade européia? ... Dois euro peus já citados - um belga e um alemão afírmam que sim. Outro, de nacionalidade suiça - Henry Valloton - percebeu aspectos londrinos na metrópole paulista, porque "pelas sete horas da noite,

\footnotetext{
(93). - ULMANN (Hermann), Brasilinischer Sommer, Verlag Grenze und Ausland, Berlin — pág. 67.

(94). - DEFFONTAINES (Pierre), Geografia Hưmana do Brasil, pág. 83, eć. do Conselho Nazional de Geografia, Rio, 1940.

(95). - HUNNICUTT (Benjamin H.) Brazil Looks forward, pág. 400, ed. do I, B.G.E., Rio, 1945 .

(96). - HARNISCH (Wolfang Hoffmann), $O$ Brasil que eu vi (Retrato de uma potência tropical), págs. $75-76$, traduçãa brasileira de Huberto Augusto, ed. Melhoramentos, São Paulo.

(97). - FIGUEIREDO' (Lima), Cidades e Sertōes (Páginas de História e geografia do Brasil), pág. 13, vol. XL da Biblioteca Militer, Rio, 1941.
} 
quando mil reclames luminosos se acendem e alegram a cidade, quando filas de empregados esperam os auto-onibus, é-se levado a pensar em Piccadilly Circus" (98). Entretanto, uma francesa, Claude Eylan, que a conheceu por volta de 1940, considerou-a "une ville bien brésilienne", nada semelhante às cidades norte-americanas, apesar de seus arranha-céus; por certos aspectos de sua vida comercial e por suas construções, seria quando muito uma cidade ítalor -americana (99).

Todavia, já não pensam assim os norte-americanos que a têm visitado, nos últimos quinze anos: chega a impressionar a unanimidade de suas opiniões no sentido de que São Paulo faz lembrar, muito fortemente, certas cidades dos Estados Unidos.

Das maiores cidades brasileiras - diz Vera Kelsey - é exatamente São Paulo a que menos atrativos oferece ao viajante norte-americano: "It so strongly resembles modern industrial cities in the United Sstates that the Nohtr American is not impressed but disappointed" ... (100). Vai mais além: o Triângulo lembraria a baixa Nova-York e as avenidas largas dos bairros residenciais seriam uma reprodução d'e Buffalo, Minneapolis ou Los Angeles (101). Dez anos mais tarde, bateu ainda uma vez na mesma tecla, com igual segurança: "With its skyscraper-and-tall-chimney skyline, its crowded, clamorous streets, its suburbs of luxurious homes, São Paulo resembles such cities as Chicago Los Angeles and Detroit"; e chegou a afirmar que os seus habitantes apresentam "a trait long considered peculiar to the North American". (102).

Com a autoridade que ninguém pode negar-lhe, por ser um geógrafo eminente e conhecer bastante a capital paulista, Preston James afirma que São Paulo, em sua recente evolução, transformou-se numa cidade que, "to a greater and greater degree, has taken on all the characteristics, good and bad, of its North American prototypes" (103).

"São Paulo é a Chicago da América do Sul" (104) ou "uma espécie de Chicago tropical" (105) - dizem outros norte-americanos. E a questão do d'esapontamento, que êles sentem ao entrar em

\footnotetext{
(98). - VALLOTON (Henry), Brésil, terre d'amour et de beauté, pág 162, Lib. Payout, Lausanne, 1945.

(99). EYLAN (Claude), Etapes Brésiliennes, págs. 166-167, Lib. Plon, Paris, 1940 (100). - KELSEY (Vera), Seven Keys to Brazil, pág. 132, ed. Funk \& Wagnalls Co., Nova-York, 1940

(101). - KELSEY (Vera), obra cit.; pág. 132.

(102). - KELSEY (Vera), Brazil in Capitals, pág. 167, ed. Harper 8t Brothers Pub. Nova-York, 1942 .

(103). - JAMES (Preston), Brazil, pág. 149, ed. The Ociyssey Press, Nova-York, $1942-46$

(104). - BROWN (Harriett McCune) e BAILEY (Helen Miller), Our Latin American Neighbors, pág. 388, ed. Houghton Mifflin Co., Boston 1944.

(105). - Em City of Enterprise, edição latino-emericana do "Time", pág. 20, Nova-York, 21 de janeiro de 1952 .
} 
contato com a metrópole paulista, de novo vem à baila: "Coming" from beautiful Rio, the visitor may be disappointed in São Paulo, for it looks a great deal like the industrial cities of the United States. Factories and skyscrapers, eletric signs, streets crowded with traffic, all remind the North American of home" (106).

Tudo parece indicar, por conseguinte, que a cidade de São Paulo assemelha-se a certas cidades dos Estados Unidos. Por outro lado. forçosamente, deve apresentar e realmente apresenta traços. capazes de recordar algumas cidades européias; além das semelhanças já apontadas, acaso não faz lembrar, sobretudo no velho centro determinados trechos da cidade do Pôrto? Mas, indepentente de tudo isso, como observou Claude Eylan, é antes de mais nada uma cidade bem brasileira, na sua fisionomia urbana como no espírito de seus habitantes, embora apresentado características que lhe são inteiramente próprias e sua originalidade.

E a cidade dos muitos contrastes, com largas avenidas, de tráfego intenso, no meio de blocos compactos de arranha-céus, como também das ruelas tranqüilas, emolduradas de prédios antigos, que fazem lembrar os tempos passados. $\mathrm{E}$ a cidade das ladeiras e dos viadutos, a "metrópole internacional", a "cidade cosmopolita" (107), a "cidade de energia", a "capital do progresso", a "grande oficina", e "capital industrial do Brasil" (108), a "capital de capital" (109), a "cidade dinâmica" e a "city of homes" (110), o grande centro cultural do país, a "cidade que mais cresce no Mundo" ...

Naturalmente, cumpre tentar encontrar uma explicação para êsse "fenômeno" urbano, que é a capital paulista; e os fatôres aparecem aos nossos olhos, ora de uma evidência irretorquivel ora menos marcantes em sua influência.

Os fatôres de ordem económica devem ser citados em primeiro lugar, porque a cid'ade de São Paulo é bem um reflexo do admirável desenvolvimento econômico registrado dentro das fronteiras do Estado e mesmo fora delas, nas áreas de influência paulista.

Com efeito, no decorrer do segundo quartel do século $\mathrm{XX}$, o Estado de São Paulo rasgou horizontes novos para sua economia: abandonou a monocultura cafeeira, para transformar-se no maior centro policultor do país. Após a crise de 1929-1930, prosseguiu a marcha do café no rumo de Oeste, com a abertura das frentes pioneiras não apenas no território paulista, mas também em o Norte

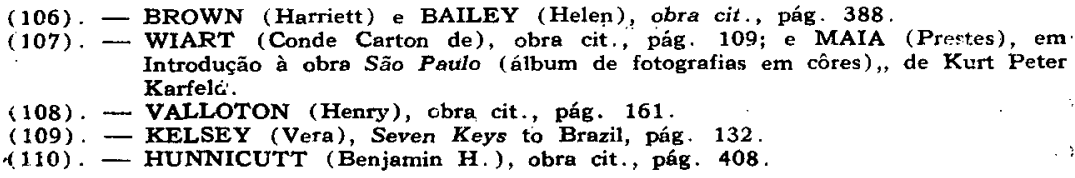
Introdução à obra São Paulo (álbum de fotografias em côres), de Kurt Peter Karfelć.

(108). - VALLOTON (Henry), obra cit., pág. 161.

(109). - KELSEY (Vera), Seven Keys to Brazil, pág. 132.

(1.10). - HUNNICUTT (Benjamin H.), obra cit., pág. 408. 
do Paraná (111). Mas, paralelamente, teve início o importante surto algodoeiro (sobretudo a partir de 1935), desenvolveu-se a cultura canavieira e novas culturas vieram a surgir .

Aa mesmo tempo, a expansão das vias de comunicações, parti-: cularmente e multiplicação e a melhoria das estradas de rodagem, puzeram a capital do Estado em contato direto com as áreas produtoras do interior e levaram a influência paulista até uma parte de Minas Gerais, ao sul de Goiás e de Mato Grosso, ao norte do $\mathrm{Pa}$ raná. O binário São Paulo-Santos, mais do que nunca, passou a comandar tôda uma vasta região brasileira.

Acrescente-se, a tudo isso, o espantoso desenvolvimento do $\mathrm{par}_{T}$ : que industrial paulistano e ninguém poderá ter dúvida que tais fatôres de natureza econômica tiveram magna pars no crescimento da ci-: dade.

O café continua a ser o grande sustentáculo da economia agrícola do Estado, embora houvesse cedido lugar a outras culturas. No período de 1931-1935, a produção foi de 990.000 ton; em 1945, foi de 209.421 ton; em 1952, de 248.000 ton. Neste último ano, o valor da produção caféeira alcançou mais 9.293 milhc̃es de cruzeiros.

Em 1930, a produção paulista de algodão foi de sòmente 6.3.78 ton; no entanto, em 1940, atingiu 307.000 e, em 1952, chegou a 337.000 to; no valor de $\mathbf{5 . 3 9 2}$ milhões de cruzeiros.

São essas as duas maiores riquezas de São Paulo e isto vem acontecendo desde a quarta década do presente século (112); em 1952, correspondiam a $70 \%$ do valor da produção agrícola do Estado.

Mas outras existem, que merecem ser referidas: o arroz (2.243 milhōes de cruzeiros, em 1952$)$, io milho (1.800 milhões), e feijão ( 540 milhões), a batata ( 529 milhões), a mandioca ( 351 milhões), o amendoim, a laranja, a mamona, etc. (113).

Em 1940, o Estado contava com $7.517 \mathrm{~km}$. de vias-férreas e

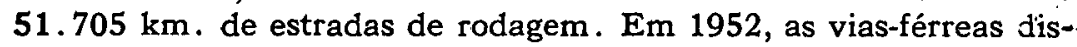
punham de $7.737 \mathrm{~km}$., ao passo que as rodovias alcançaram o total de $89.357 \mathrm{~km}$.

Espantoso, porém, foi o aumento verificado no valor da produção industrial: ao passo que no periodo de 1928-1932, a média do valor da produção industrial era, apenas, de $41 \%$ do totạl, em 1950 alcançou $80 \%$ ! (114).

\footnotetext{
(111). - Consulte-se, entre outros: MILLIET (Sérgio), 'Roteiro do Café, S. Paulo, 1938; MON'BEIG (Pierre), Pionniers et Planteurs de São Paulo,' Lib. Armand Colin, 1952 .

(112). - Veja: FACULDADE DE CIENCIAS ECONÓMICAS DE SÃo PAULo (Alunos da), Duas riquezas de São Paulo: café e algodão, no vol. IV “Anais" do IX Congresso Brasileiro de Geografia, Rio, 1944.

(113). - Cf. Comércio Internacional, Boletim Mensal do. BANCO Do BRASIL, ano III, n. ${ }^{\circ} 3$, Rio, outubro de 1953 , pág. 56.

(114). - Cf. Comércio Internacional, N.o citado, pág. 54.
} 
Todavia não se poderá deisar no esquecimento um outro fator: a imigração. São Paulo continuará a ser a "cidade cosmopolita", foco de irresistivel atração dos elementos alienígenas fixados no Estado - italianos, ibéricos, japoneses, sírio-libaneses, armênios, húngaros, lituanos judeus, etc. ou de seus descendentes brasileiros pelo nascimento. Mas, notadamente, centro de convergência de brasileiros de outros Estados e do próprio território paulista, atraidos pela miragem da metrópole movimentada e dinâmica, sobretudo a partir do ano de 1934 .

Em 1920, existiam no Estado 829.851 estrangeiros, dos quais 93\% eram europeus e 5\% eram asiáticos. Em. 1940, o total caiu para 761.991 , dos quais $77 \%$ europeus e $20 \%$ asiáticos. $\mathrm{Em} \mathrm{1950,}$ não existiam mais de 627.433 estrangeiros em território paulista.

Essa constạnte diminuição do elemento alienígena explica-se pelas restrições, registradas nos movimentos migratórios (tanto para a entrada no território nacional, como para a saida dos países de emigração) e pela segunda Guerra Mundial (1939-1945).

Em compensação, porém, aumentaram sempre as entradas de imigrantes nacionais. Eis algumas cifras referentes a anos próximos:

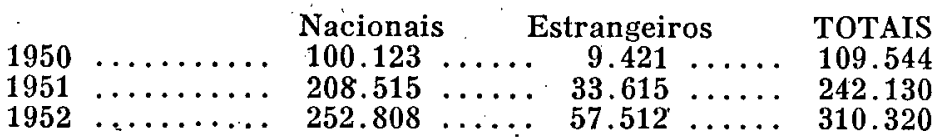

Todos os fatôres citados, econômicos ou demográficos, palpitam bem vivos na capital paulista. Sentímo-los na potencia de sua vida comercial, na quantidade e movimento de seus bancos, na fôrça de suas indústrias variadíssimas, no ininterrupto despejar de gente que se presencia nas estações ferroviárias e rodoviárias. Sentímo-los, finalmente, na própria massa da população urbana, em que se encontram, de mistura, tipos alourados, morenos, negros, amarelos ou mestiços, brasileiros de tôdas as regiões, homens vindos da Europa, da Ásia e da América do Norte.

Como não poderia deixar de acontecer, êsse São Paulo do segundo quartel do século $\mathrm{XX}$ vio expandir-se desmesuradamnte sua área urbana e exigiu importantes transformações de caráter urbanístico

A expansão urbana, de 1925 a 1950, não se processou da mesma maneira em tôdas as direções, nem os tentáculos da cidade caminharam de forma homogênea e equilibrada. No rumo do Norte, a cidade atravessou o Tietê, pontilhou aqui e ali a grande várzea e foi ocupar extensas áreas ao pé da serra da Cantareira; favoreceu essa marcha a conquista da várzea pelo homem retificação parcial do 'Tietê, obras de drenagem e aterramento), 
ao thesmo tempo que condicionou tal expansão o Tramway da Cantareira, através de suas duas linhas distintas, para Tremembé e para Guarulhos. Entretanto, o avanço nessa direção foi relativamente pequeno e a região de além Tiete continuou a formar um bloco à parte, dentro do organismo urbano.

No rumo de Ooeste, a cidade ligou-se definitivamente à Lapa e, mesmo, a ultrapassou graças à ocupação da zona marginal das vias-férreas e à radial Avenida Âgua Branca-Rua Guaicurús, ao sul d’a qual, já no espigão divisor Tietê-Pinheiros, vieram a surgir bairros operários e de classe média.

Para Leste, o velho subúrbio da Penha também foi alcançado pelos tentáculos da cidade e, até, ultrapassado, margeando os trilhos da "Central do Brasil', como ainda a radial Avenida Celso Garcia-Estradá de São Miguel, multiplicaram-se os bairros de aspecto modesto, moradia da população operária. No caso presente, foi pròpriamente - Brás que se expandiu, levando os limites da cidade a uma distância de $10 \mathrm{~km}$. do centro (115).

Para Sudeste, também foi a via-férrea que presidiu a expansão: o Ipiranga viu-se ligado à cidade e, mais além novos bairros surgiram preparando a marcha no rumo de São Caetano e Santo André. Corresponde à direção em que o avanço 'foi mais forte, não pròpriamente na distância, mas pela rapidez da ocupação do solo; e, ainda uma vez, os bairros proletários passaram a caracterizá-la.

Para o Sul, a metrópole em marcha emitiu o seu mais alongado tentáculo, pois conseguiu alcançar o velho núcleo de Santo Amaro, dominando-o por tal forma, que the tirou a autonomia administrativa. A linha de bondes, as estradas de rodagem ,a construção das represas da Light - tudo isso concorreu para que numerosos bairros residenciais de classe média e algumas indústrias ali viessem a se instalar, extendendo a influência da cidade até um raio de mais de $15 \mathrm{~km}$.

No rumo de Sudoeste, finalmente, verificou-se uma expansão bem diversa das citadas até aqui; nem as vias de comunicação. muito menos as indústrias podem explicá-1a, mas, tão sòmente, o reflexo da prosperidade econômica do Estado e da própria capital. Iniciado o loteamento ainda no primeiro quartel do século e introduzidos os ïndispensáveis melhoramentos, que o terreno brejoso ou acidentado exigiam, desenvolveram-se, sem demora, bairros residenciais finos, dos mais belos e elegantes da cidade: o Jardim América, o Jardim Europa, o Pacaembú, o Sumaré. E assim tinha de acontecer, pois as despesas realizadas com aquêles melhoramentos só poderiam elevar o custo de seus terrenos, ocasionando uma natural sele-

(115). - Consulte-se AZEVEDO (Arolóo de), Subúrbios Orientais de São Paulo, São Paulo 1945. 
ção no que se refere aos seus habitantes. Preencheu-se, assim, o vazio existente entre o tentáculo que se dirigia para Santo Amaro e o que, em marcha mais vagarosa e de feição mais modesta, encaminhou-se em direção ao velho núcleo de Pinheiros.

E preciso acentuar que a partir da terceira década do século atual, às linhas de bondes vieram juntar-se as de ônibus, no quase norteamento do crescimento de algumas áreas da cidade, particularmente as que preencheram. "vazios" existentes entre os tentáculos da cidade.

Em consequiência dessa expanśão, afastadios subúrbios do São Paulo do primeiro quartel do século $\mathrm{XX}$ passaram a constituir, na etapa seguinte, bairros e arrabaldes da metrópole em crescimento.

Os subúrbios da cidade passaram a ser bem outros: Itaquera, São Miguel, Lajeado, Ferraz de Vasconcelos, Poá, Itaquaquecetuba, para as bandas de Leste, na zona da "Central do Brasil" (116); São Caetano; Santo Anđré e Mauá, na direção de Sudeste, junto à "E. F. Santos-Jundiá̂"; Itapecerica e Cotia, um tanto afastados, no rumo de Sudoeste; Osasco, Duque de Caxias e Baruerí, para ocidente, ao longo da "Sorocabana"; Pirituba, Perús e Caieiras, na direção de Noroeste, margeandio a "Santos-Jundiấ"; Tremembé, Vila Galvão e Guarulhos, ao Norte, na região da Cantareira (117).

Em última análise: uma extensa área periférica que não difere essencialmente da que hoje conhecemos como tal, exercendo funções variadas - residencial, industrial e mesmo agrícola (118).

Aa mesmo tempo que São Paulo via expandir-se sua área urkana, importantes transformações urbanisticas foram registradas. Em obra publicada em 1944, Paulo Henrique descreveu muito bem a cidade ao iniciar-se a quarta década do século:

"Sob um céu sempre opaco e disputado entre a neblina da Serra e a fumaça das fábricas, a cidade, irregular no traçado, na topografia e nas construções, pouco atraía. Imagine-se cêrca de um milhão de habitantes formigando entre ruas acanhadas, cheias de fumaça, aos empurrões com operários e imigrantes. De vez em vez, ia-se ter a uma bonita praça donde se viam algumas esporádicas edificações de vulto. Não se cogitava da urbanização de hoje. Só em alguns bairros residenciais as construções eram regularmentadas. Mas o centro, a parte vital da cidade e por onde se tinha de passar obrigatòriamente quando de um bairro se demandasse outro, era vitimado por um congestionamento permanente do

(116). - AZEVEDO (Aroldo de), obra cit., cap. II e seguintes.

(117) - AZEVEDO (Aroldo dc), Suburbios de São Paulo (Primeiros estudos,) em Anuário da Faculdade de Filosofia do Instituto "Secies Sapientiae", São Paulo, 1943.

(118) - - AZEVEDo (Aroldo de), Os Subúrbios de São Paulo e suas funções, em "Boletim da Associação dos Geógrafos Brasileiros", ano IV, n. ${ }^{\circ} 4$, págs. 59-69, São Paulo, maio de 1944. 


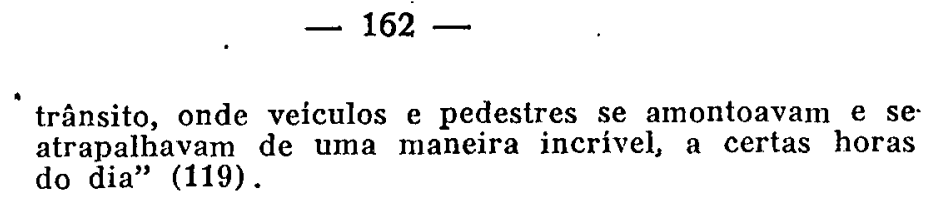

Coube ao prefeito Fábio Prado (1934-1938) iniciar a renovação da capital paulista dentro das modernas diretrizes do urbanismo; no entanto, foi o prefeito Prestes Maia o verdadeiro autor da remodelação da cidade, durante sete anos de administração (1938-1945). No desejo de arejar o centro e desafogar o tráfego cada vez mais intenso, abriram-se as avenidas perimetrais e irrzdiação, largas de 33 e 45 metros, intercaladas por numerosas praças; iniciou-se a abertura do segundo anel envolvente de avenidas e deu-se um impulso definitivo ao chamado "sistema Y", com suas avenidas de fundo vale, facilitando as comunicações entre o Sul e o Norte da M'etrópole; alargaram-se numerosas ruas e praças, tanto do rio Tiete, encurtando de $20 \mathrm{~km}$. seu curso meândrico e propiciando a recuperação de $17 \mathrm{~km}^{2}$ de terras varzeanas (120). Largas e extensas avenidas, arranha-céus substituindo velhos pardieiros mal arejados e inestéticos deram à área central da cidade uma fisoinomia inteiramente nova. Não há nenhum exagêro em dizer-se que, nesse período, teve lugar a quarta fundação de São Paulo, uma. vez que as transformações foram de maior vulto do que as verificadas nas administraçōes de Antônio Prado e João Teodoro.

Surgiu, assim, no segundo quartel do presente século a cidade que hoje conhecemos, com todos os característicos - bons e maus. - das grandes metrópoles do Mundo.

\section{SÃO PAULO ATUAL E SUAS PRINCIPAIS CARACTERISTICAS. OBRAS CONSULTADAS}

Antes de mais nada, o que causa espanto na capital paulista é sua enorme extensão; e neste particular, assemelha-se realmente: muito mais às cidades norte-americanas do que às européias. Já não. se percebe, como há poucos anos, os seus imensos tentáculos; a metrópole atual apresenta-se como um conjunto mais ou menos harmônico, como um bloco imenso de bairros que, sobretudo ao sul do. Tietê, extendem-se de maneira compacta num raio de 7 a $8 \mathrm{~km}$. Proporcionalmente ao número de seus habitantes, ocupa uma área. bem maior do que Londres ou Paris.

\footnotetext{
(119). - HENRIQUE (Paulo), Metrópole e Rincōes (Ensáios), pág. 25, Säo Paulo. 1944.

(120). - Sôbre o assunto, consulte-se: MAIA (Francisco Prestes), Estudo de um Plano de Avenidas para a Cidade de São Paulo, Comp. Melhoramentos, São Paulo, 1930; São Paulo, metrópole do sécut $X X$, Emprêsa de Publicações Associacias, Sāo Paulo, 1942; e MAIA (Prestes), Introdução à cbra São Paulo (álbum com fotografias em côres) de Kurt Peter Karfeld, ed. Melhoramentos, São Paulo. 1953 .
} 
Sua estrutura urbana, todavia é irregular e desordenada. Salvo quanto a certos trechos da área central e nuns poucos bairros nenhum plano urbanístico norteou ou disciplinou seu espantoso crescimento. As sucessivas administrações municipais não conseguiram acompanhar o ininterrupto desenvolvimento da cidade. Os loteamentos modernos embora isoladamente atendam aos requisitos do urbanismo assim não se apresentam quando considerados no conjunto pois acabam por constituir um averdadieira colxa de retalhos sem nenhuma harmonia ou entrosamento.

Três grandes áreas constituem a cidade de São Paulo atualmente: 1. o núcleo principal compacto e enorme situado entre o Tietê e o Pinheiros que se alonga no sentido Ooeste-Leste dos extremos da Lapa até às vilas satélites da Penha e no rumo de Sudeste, confundindo-se já com São Caetano do Sul: 2. a área de além Tietê, ao norte dêste rio, com uns poucos núcleos antigos (Freguezia do Ó, Sant'Ana), embora se caracterize por um desenvolvimento recente, realizado em forma fragmentária, e que também se alonga no sentido Leste-Oeste, desde Vila Maria até Pirituba; 3. a área de Pinheiros, à margem dêste rio, cheia de contrastes, extendendo-se desde o Butantã até Santo Amaro.

A primeira área corresponde, pràticamente, à verdadeira cidade; nela encontramos o centro comercial, os principais bairros industriais e os mais importantes bairros residenciais. A segunda só agora começa a integrar-se ao aglomerado, graças sobretudo ao desenvolvimento do Tucuruvi e arredores. A terceira área, finalmente, encontra-se em grande parte em franco prccesso de aglutinação, em virtude de numerosos loteamentos feitos em época secente.

Embora não mais ofereça o aspecto fragmentário e estelar do primeiro quartel do século, São Paulo ainda possui um número elevado de trechos vaziosi, dentro da área urbano. Os mais extensos correspondem às várzeas do Tietê e do Pinheiros; mas também êles aparecem em numerosos vales dos córregos e ribeirões paulistanos, até mesmo não longe do centro da cidade, sobretudo quando se trata de suas cabeceiras.

A retificação e canalização dos dois maiores rios paulistanos, a par de outras obras complementares (dragagem, drenagem e aterramento das várzeas, abertura de vias públicas, etc), concorreram poderosamente para a ocupação dessas áreas, através de prolongamentos de bairros já existentes ou do aparecimento de bairros bairros novos. Daí o menor isolamento que hoje se constata em relação à área situada ao norte do Tietê que não tardará a unir-se completamente ao núcleo principal da cidade; o fato está patente no levantamento aero-fotográfico, realizado em novembro de 1952 
pela "Cruzeiro do Sul". Neste particular. verifica-se que a várzea do Pinheiros está sendo conquistada com muito maior rapidez, o que talvez possa ser explicado pela proximidade de bairros tesidenciais finos.

Por outro lado, chega a impressionar a enorme extensão dos loteamentos na periferia da cidade; e acreditamos não estar enganados ao afirmar que tais áreas equivalem, senão ultrapassam. aos trechos efetivamente ocupados. $\mathrm{Na}$ verđade, a especulação imobiliária fêz com que fôssem arruadas e loteadas extensas áreas, próximas ou bastante afastadas da cidade, chegando-se a calcular que, se forem realmente ocupadas, darão guarida a mais de $30 \mathrm{mi}$ lhões de pessoas.

Tudo isso serve para demonstrar a maneira completamente anormal e sem nenhum planejamento pela qual se vão processando tais loteamentos. Mais grave ainda é o fato de estarem sendo ocupadas áreas muito distantes do centro da cidade, ao mesmo tempo que, dentro dela, continuam a existir vazios, à espera de valorização.

Certos loteamentos agem como fatôres do retardamento da expansão normal da cidade; neste caso encontram-se os terrenos baldios da área urbana, assim deixados à espera de melhores preços.

Outros loteamentos, porém, influem sôbre o crescimento da cidade e chegam a orientar sua expansão. Uns são oferecidos a baixo preço, atravéz de prestações módlicas, quando não acompanhados por uma certa quantidade de tijolos. Naturalmente, o paulistano de escassos recursos, atormentado pelo pagamento dos aluguéis e pelo desconfôrto da pequena casa ou do "cortiço" situados na cidade, não tem dúvida em adquirir o seu lote, no justificado anseio de possuir sua casa própria, embora grandes distâncias venham a separá-lo do local em que trabalha. Daí o rápido crescimento de uma infinidade de "vilas", que surgem como cogumelos nos arredores e nos subúrbios da metrópole. De outro tipo são os loteamentos de preços altos, com terrenos de maior área e dotados de comodidades que os anteriormente citados são conhecem; encontram-se no: próprio perímetro urbano ou em sua periferia e não tardam a transformar-se em bairros residenciais de classe média ou mesmo rica. Embora ocupem áreas maiores, sua densidade demográfica é, evidentemente, muito menor que os do tipo atrás citado.

Também ligado é especulação imobiliária é o característico que faz São Paulo recordar, no seu aspecto, as grandes cidades dos Estados Unidos: o número sempre crescente de arranha-céus: A princípio, limitavam-se à área central, onde hoje constituem um bloco maciço e impressionante, um dos maiores do mundo, com numerosos edifícios de mais de 20 andares. No entanto, nas áreas periféricas ao centro e mesmo longe (no espigão da Avenida Pau- 
lista, por exemplo), suas silhuetas já aparecem, demonstrando que a cidade também cresce em altura.

Antes de 1920, constituiam exceções os prédios de mais de três ou quatro pavimentos. Construido em 1929, o Prédio América (ex-Martinelli), na ladeira inicial da Avenida de São João, com seus 26 andares, foi durante muito tempo o único arranha-céu da cidade. Mas, a partir da década 1930-1940, seu número passou a ser cada vez maior.

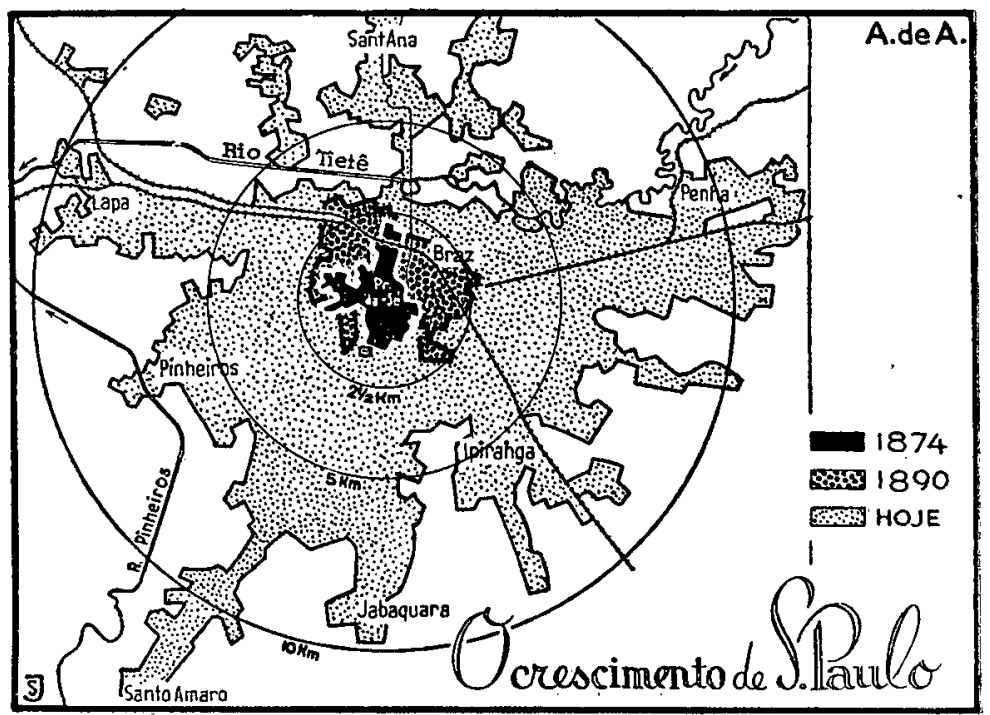

Apud Aroldo de Azevedo, Subúrbios de São Paulo e suas funções.

Apesar das idéias em contrário, julgamos que tais edificações gigantescas, construidas para escritórios ou para apartamentos residenciais, vieram solucionar, em parte, o problema criado pelo desmensurado crescimento da cidade: oferecem vantagens quanto à insolação e ao arejamento e, em se tratando da área central ou de sua periferia, facilitaram o problema do tráfego urbano, pois pràticamente dispensam a utilização de veículos para os que neles habitam. Em contraposição, porém, começam a criar embaraços muito sérios em virtude da maior densidade demográfica que vieram ocasionar, pois as rêdes de água e esgotos atualmente existentes na área em que se encontram já não atendem às necessidades da massa de habitantes que delas se utilizam.

Em sua avassaladora expansão, a capital paulista não se limitou a realizar as conurbanizações a que já fizemos referência. 
Graças à melhoria das vias de comunicação, notadamente no setor rodoviário, e ao estabelecimento de um admirável serviço de transportes, São Paulo já possui numerosas cidade satélites, que gravitam ao seu redor. E' o caso de Santos, de Mogi das Cruzes, de Jundiaí, de São Roque, que começam a apresentar, sob certos aspectos, as características de subúrbios afastados da Paulicéia.

$\mathrm{Na}$ verdade, em menos de duas horas pode-se atingir tais cidades vizinhas, sendo intenso o tráfego de ônibus, automóveis de aluguel, caminhões de carga e de trens em sua direção. Depois da construção da Via Anchieta, de três em três minutos parte um ônibus para a cidade de Santos, que se transformou em local preferido para passar os fins de semana, além de continuar a ser o grande pôrto da cidade e do Estado.

Tudo parece indicar que, pelo menos por alguns lustros mais, São Paulo manterá seu atual ritmo de crescimento. Talvez para - Norte, em direção à Cantareira, essa marcha venha a cessar mais depressa, em razão do obstáculo oferecido pela serra. Noutras direções, porém, a expansão não encontra barreiras e torna-se difícil prever até onde chegará.

Sente-se, apesar disso, que a cidade obedece a certas diretrizes em sua expansão, sobretudo para Leste, para Sudeste, para o Sul e para Oeste.

No rumo de Lente, os subúrbios orientais tornam-se cada vez mais densamente povoados, graças à melhoria das vias de comunicação (eletrificação da "Central do Brasil", existência de linhas regulares de ônibus que partem da Penha, a própria Rodovia Presidente Dutra e suas ligações). Foi acentuada a sua função residencial (principalmente de operários) e cresceu sua função industrial, de que São Miguel Paulista e Comendador Ermelino são bem o símbolo.

Para Sudeste, acompanhando a "Santos-Jundiaí" e a Via Anchieta, a cidade marcha decididamente, englobando na esfera de sua influência, cada vez mais, as atuais cidades de São Caetano do Sul, Santo André e São Bernardo do Campo.

Para o Sul, Santo Amaro integra-se cada vez mais na área urbana paulistana, sobretudo depois do alargamento e da pavimentação da grande avenida que liga os dois centros. O próprio núcleo de Santo Amaro, durante tanto tempo estagnado, amplia-se consideràvelmente, não apenas nos bairros surgidos às margens das grandes represas da Light, mas no próprio aglomerado. Por outro lado, a abertura da Avenida Nove de Julho e da Avenida Cidade Jardim vieram abrir uma nova frente de expansão de âmbito imprevisivel. Apesar de umas poucas indústrias, já ali instaladas, tudo indica que tal área virá a ser um dos mais belos trechos residenciais da cidade. 
No rumo Oeste, a Lapa cada vez mais se expande, integrando definitivamente Osasco na área urbana, como também Pirituba. A presença das duas vias-férreas (a "Santos-Jundiaí" e a "Sorocabana"), como a Via Anhanguera são fatôres estimulantes dessa expansão e propiciam o fortalecimento dos bairros industriais e operários ali já instalados. Para os lados do rio Pinheiros, o mesmo fenômeno se verifica: o Alto da Lapa tende a unir-se com a Vila Industrial Jaguaré e a Cidade Universitária (em construção), por sua vez ligadas ao Alto de Pinheiros e ao Butantã.

Tudo isso repercute, naturalmente, noutros aspectos da cidade: no impressionante crescimento de sua população, na ininterrupta febre de construções, na multiplicidade de suas funções.

$\mathrm{O}$ segundo quartel do século $\mathrm{XX}$ assistiu o espetacular crescimento da população da cidade: tendo cêrca de um milhão de habitantes por volta de 1930 , passou o municipio a ter $1.326 .281 \mathrm{em}$ $1940,2.227 .512$ em 1950, quase 3.000 .000 no ano de seu quarto centenário.

"Em grandeza e importância - observa Prestes Maia - é a terceira cidade latina do Mundo, depois de Paris e Buenos Aires e a par do Rio de Janeiro" (121). Na década de 1940-1950, ao passo que Rio de Janeiro registrou um aumento de $28 \%$, São Paulo cresceu 68\%; e deixa longe Nova York, Chicago, Buenos Aires ou Madrí, neste particular (122). Indubitàvelmente, é hoje a cidade mais populosa do país e já foi considerada, não apenas a que mais cresce no Mundo, mas a em que mais gente transita pelas ruas (123). - No que se refere à construção de prédios, parece não existir nenhuma cidade que a iguale: não há rua que não ofereça um telhado novo, raras são as que não assistem à construção de um prédio. Prédios residenciais, finos ou modestos, palacetes ou bangalôs estandartizados, arranha-céus, de 8 ou 10 andares e gigantes de mais de 25 andares, com sua estrutura de cimento armado. Enquanto em Nova York constroi-se, cada ano, um casa para cada grupo de 423 habitantes, em Buenos Aires para 134, em São Paula registrase a média de 102 (124). Nos últimos anos, o aumento médio anual de prédios foi de 18.000 (125), embora já se tenha registrado um total de mais de 24.000 por ano. Pode-se afirmar, sem receio de errar, que se constroi em São Paulo uma casa em cada 20 minutos!

\footnotetext{
(121). - MAIA (Prestes), na Introciuçăo à obra São. Paulo, já citada.

(122). - Cf. listo é São Paulol, ed. Melhoramentos, São Paulo.

(123). - Cf. ARROYO (Leonardo), em São Paulo Antigo e São Paulo maderno, ed. Melhoramentos, São Paulo.

(124). - Cf. ARROYO (Leonardo), obra cit

(125). - Cf. MAIA (Prestes), obra cit.
} 
Em 1932, existiam 106.327 prédios na cidade (126); hoje êste número pode ser avaliado em 410.000 . Nos últimos quatro anos, construiram-se 90.000 prédios na capital paulista, enquanto, no mesmo período, construiram-se 50.000 em tôdas as demais capitais brasileiras reunidas.

Tudo cresceu, espantosamente, na última década: o número de fábricas e de operários, as casas de comércio, o total de profissionais, os veículos, os telefones, o movimento de seu aeroporto, o número de ruas, os templos, os abastecimento. E a presente obra, de que nosso estudo é um simples capítulo, testemunha eloqüentemente esta afirmativa.

Limitar-nos-emos a registrar algumas cifras expressivas. Nas 20.000 fábricas paulistanas, trabalham $\mathbf{4 4 0 . 0 0 0}$ operários, o que significa que, em cada grupo de 7 habitantes, um é operário. Em suas 8.800 ruas, exsitem 36.000 casas de comércio. Trafegam pela cidade cêrca de 150.000 veículos, 75.000 dos quais são automóveis, 40.000 bicicletas, 22.000 camnihões, 5.000 de tração animal (pouco mais de $3 \%$ ), 3.000 ônibus, 2.000 motocicletas, 800 bondes. $O$ número de telefones ascende a 140.000 e o de aparelhos de rádios. chega a 40.000 , existindo 12 estações de rádio e 3 de televisão. $O$ município possui 44 estações de estradas de ferro e $135 \mathrm{~km}$ de trilhos. O aeroporto de Congonhas recebe, anualmente, a média de 40.000 aviões. Existem 200 templos católicos, 98 protestantes, 12 sinagogas, 5 grego-cismáticos e um budista. Nada menos de 804 estabelecimentos primários, 111 ginásios, 56 colégios, 19 escolas normais, 18 estabelecimentos de ensino superior, três Universidades, 15 estabelecimentos de ensino agrícola e industrial, 393 escolas de corte, costura e arte culinária, etc., atendem ao aspecto educacional e cultural de sua população. Existem 449 tipografias, 203. revistas, 106 livrarias, 91 jornais (em várias línguas) e 45 casas: editôras. No setor das diversões, há 150 cinemas, 8 teatros e 5 cineteatros. O Mercado Central da cidade pode ser considerado um dos mais variados do Mundo, chegando a oferecer mais de 300 . produtos diferentes, em determinadas épocas do ano. A população consome 315 ton. de carne por dia, 10 milhões de dúzias de ovos, 2.000 ton. de manteiga, 720.000 sacas de farinha, por ano, e 180.000 sacas de arroz e 60.000 sacas de feijão, cada mês. Isto é São Paulo, no ano em que comemora o seu quarto centenário.

Poderíamos encerrar estas considerações lembrando as palavras de Doménico Bartolotti, um europeu que, como tantos outros, teve expressões de admiração em face do fenômeno urbano representado por São Paulo. Entre outras coisas, Bartolotti acentua que

(126). - Cf. QUEIROZ (Vitorino Seixas), e ARANTES JUNIOR (Lourençn), Os Municipios do Estado de Sáo Paulo, pág: 114. 
a cidade de São Paulo caracteriza-se "pelo trabalho febril, fecundo, intermitente, voltado para o desêjo da criação e da construção, entremeado por sonhos de grandeza e de ambição, vibrante pela ardente febre da novidade (127).

- Como o próprio Bartolotti, entretanto, somos tomados pela dúvida sôbre as vantagens e o sentido da presença dessa monstruosa metrópole que está transformando o Estado de São Paulo em um corpo que definha mas que orgulhosamente ostenta soberba macrocefalia. Torna-se lícito perguntar-se "o que se tornará esta cidade em contínua renovação e desenvolvimento; e se esta espécie de elefantiase é explicável e justificada" (128).

\section{PASQUALE PETRONE}

\section{OBRAS CONSULTADAS}

1. Almanaque Brasileiro para o ano de 1907 - Ano V - Garnier - Rio de Janeiro.

2. ARRoIo, Leonardo - in São Paulo Antigo e São Paulo Moderno - Melhoramentos - São Paulo.

3. AZEVEDO, Aroldo - Os Subúrbios de São Paulo e suas funções - in "Boletim da Associação dos Geógrafos Brasileiros" - Ano IV - n.o 4 - São Paulo - maio de 1944.

4. AZEVEDO, Aroldo de - Subúrbios de São Paulo - Primeiros Estudos - in "Anuário da Faculdade de Filosofia do Instituto Sedes Sapientiae" - São Paulo - 1943.

5. AZEVEDO, Aroldo de - Subúrbios Orientais de São Paulo São Paulo - 1945 .

6. AZEVEDO, Sálvio Almeida - Imigração e Colonização no Estado de Sâo Paulo - in "Revista do Arquivo Municipal" Vol. LXXV - São Paulo - 1941.

7. BANDEIRA JÚNIOR, Antônio Francisco - A Indústria no Estado de São Paulo em 1901 - Tip. do Diário Oficial São Paulo - 1901 .

8. BARTOLOTTI, Domenico - Il Brașile Meridionale - Alberto Stock - Roma - 1930 .

9. BERNARDES, Manuel - El Brasil - su vida, su trabajo, su futuro - Buenos Aires - 1908.

10. BRAZIL, Raimundo Pereira - Sâo Paulo, fôrça econômica Emp. Gráfica "Revista dos Tribunais" - São Paulo — 1949.

11. BROWN, Harriett McCune e BAYLEY, Helen Miller - Our Latin American Neighbors - Houghton Mifflin Co. - Boston

12. BRUNO, Ernani Silva - História e Tradições da cidade de São Paulo - Vol. III - José Olímpio - Rio de Janeiro - 1954.

13. CAPRI, Roberto - O Estado de São Paulo e seus Municípios Tip. Pocai \& Weiss - São Paulo - 1922.

14. CAPRI, Roberto - Sáo Paulo, a Capital Artística, na comemoração do Centenário - São Paulo - 1922.

(127). - BARTOLOTTI (Domenico), Obra cit.. pág. 202

(128). - BARTOLOTTI (Domenico), Obre cit., pág. 203. 
15. Comércio Internacional - in "Boletim Mensal" do Banco do Brasil - Ano III - n..$^{\circ} 3$ - Rio de Janeiro - outubro de 1953.

16. DEBENEDETTI, E. e SALMONI, A. - Architettura Italiana a San Paolo - Instituto Cultural ftalo-Brasileiro - São Paulo

17. DEFFonTAINES, Pierre — Geografia Humana do Brasil -1953 .

Conselho Nacional de Geografia - Rio de Janeiro - 1940.

18. DENIS, Pierre - Le Brésil au XXe. siècle - Lib. Armand Colin - Paris - 1911.

19. DENIS, Pierre - Amérique du Sud - Tomo XV - 1a. parte - Lib. Armand Colin - Paris - 1927.

20. EGAS, Eugênio - Galeria dos Presidentes do Estado de São Paulo - Vols. II e III - São Paulo - 1927.

21. EGAS, Eugênio - Os Municípios Paulistas - São Paulo - 1925.

22. EYLAN, Claude - Etapes Brésiliennes - Lib. Plon - Paris - 1940 .

23. Faculdade de Ciências Econômicas de São Paulo (alunos da) - Duas riquezas de São Paulo: café e:algodâo _ Anais do IX Congresso Brasileiro de Geografia - Vol. IV - Rio de Janeiro - 1944 .

24. FIGUEIREDO, Lima - Cidades e Sertões - Páginas de História e Geografia do Brasil — Biblioteca Militar - Rio de Janeiro - 1941 .

25. FREITAS, Afonso A. de - Geografia do Estado de São Paulo - Escolas Profissionais Salesianas - São Paulo - 1906.

26. GAFFRE, L. A. - Visions du Brésil — Aillard. Alves \& Cia.

- Paris - 1912.

27. GERGE, Pierre - La Ville - Le fait urbain à travers le Monde - Presses Universitaires de France - Paris - 1952.

28. HARNISCH, Wolfgang Hoffmann - O Brasil que eu Vi. Retrato de uma potência tropical - Melhoramentos - São Paulo.

29. HESSE-WARTEGG, Ernst von - Zwischen Anden and Amazonas - Union Deutsche Verlagsgesellschaft - Stuttgart 1915.

30. HUNNICUTT, Benjamin H. - Brazil Look forward - I.B.G.E. - Rio de Janeiro - 1945.

31. HENRIQUE, Paulo - Metrópoles e Rincões - Ensaios - São Paulo - 1944.

32. JAMES, Preston - Brazil - The Odyssey Press - New York 